\title{
THE ECONOMIC WeLFARE COST OF CONFLICT: AN EMPIRICAL ASSESSMENT
}

\author{
GREGORY D. HESS
}

CESIFO WORKING PAPER NO. 852

CATEgory 1: Public FinANCE

FEBRUARY 2003

\begin{abstract}
Presented at CESifo Area Conference on Public Sector
ECONOMICS, MAY 2002
\end{abstract}

An electronic version of the paper may be downloaded

- from the SSRN website: www.SSRN.com

- from the CESifo website: www.CESifo.de 


\title{
THE ECONOMIC WELFARE COST OF CONFLICT: AN EMPIRICAL ASSESSMENT
}

\begin{abstract}
War, whether external or internal, large or small, is a costly endeavor. Loss of life, loss of close friends or family, and the destruction of material possessions all play a part in the costs of war. The purpose of this paper is to capture only the material, economic welfare costs of conflict stemming from the altered path of consumption resulting from conflict. As such, the measure is quite a lower bound for the true and more encompassing welfare loss from living in a non-peaceful world. But how much would individual be willing to pay to avoid just the economic costs of conflict? Remarkably, even these pure economic welfare losses from conflict are quite large. I find that, on average, individuals who live in a country that has experienced some conflict during the 1960-1992 sample would permanently give up to approximately 8 percent of their current level of consumption to live in a purely peaceful world. Such large potential welfare gains from reducing warfare should make economists and policy-makers take note, and continue to investigate and advocate for domestic and international institutions to realize such gains.
\end{abstract}

JEL Classification: E21, E32, H56.

Keywords: growth, conflict, welfare costs.

\author{
Gregory D. Hess \\ Claremont McKenna College \\ Department of Economics \\ 500 E. Ninth St., Bauer Center \\ Claremont, CA 91711 \\ USA \\ gregory.hess@claremontmckenna.edu
}

I would like to thank Mark Bils, Chuck Carlstrom, Ehsan Choudhri, Allesandro Cigno, Todd Clark, Ben Craig, Andy Feltenstein, Ed Mansfield, Marc Weidenmier, and seminar participants at the Federal Reserve Bank of Cleveland, the IMF Institute, and the CESifo Conference on Public Sector Economics for useful comments. Ed Pelz also receives many life-long thanks for his contribution and assistance. Part of this paper was written while I was affiliated as a visiting scholar with the Federal Reserve Bank of Cleveland and the IMF Institute. The opinions expressed are those of the authors and do not necessarily reflect views of the Federal Reserve Bank of Cleveland, the Federal Reserve System, or the IMF. 
... when the army engages in protracted campaigns, the resources of the state will not suffice.

The Art of War, Sun-Tzu (1963) p.73.

Mankind does have the capacity, over time, to correlate the costs and benefits of universal undertakings. Throughout much of the time for which we have a record of human behaviour, mankind can clearly be seen to have judged that war's benefits outweighed its costs, or appeared to do so when a putative balance was struck. Now the computation works in the opposite direction. Costs clearly exceed benefits.

A History of Warfare, John Keegan (1993) p. 59.

War may sometimes be a necessary evil. But no matter how necessary, it is always an evil, never a good.

Nobel Prize Acceptance Speech, Jimmy Carter (2002).

\section{Introduction}

Conflict can have many deleterious effects on the well-being of individuals. First, there is the destruction and loss of life that directly results from war. Turmoil also leads to decreased and uncertain supplies of necessities as the means of production are redirected from consumer goods to those necessary for the war effort. Emotional pain and suffering, forced conscription, in addition to the very real possibility of death, although difficult to quantify, add significantly to the cost of conflict. Keegan (1993) remarks that:

Some of these costs [of war] are material. The superinflationary expense of weapon procurement distorts the budgets even of the richest states, while the poor states deny themselves the chance of economic emancipation when they seek to make themselves militarily formidable. The human costs of actually going to war are even higher. Rich states, as between themselves, recognise that they are not to be borne. Poor states which fall into war with rich states are overwhelmed and humiliated. Poor states fight with each other, or are drawn into civil war, destroy their own well-being, and even the structures which make recovery from the experience of war possible. War truly has become a scourge, as was disease through most of human history. Keegan (1993) p. 59.

Many other authors have also suggested that the $20^{\text {th }}$ century has brought forth changes in terms of regime as well as technological change in mass destruction such that no nation can be expected 
to gain economically from conflict-e.g., Howard (1983, p. 22), Pigou (1940, pp. 21-22), Robbins (1942, pp. 68 and 71) and Wright (1965, pp. 242 and 1367). ${ }^{1}$ Needless to say, war provides no reasonably expected prospects for economic or personal betterment for ordinary citizens. ${ }^{2}$

Of course, this opens up the question of why we observe conflict despite it making representative individuals worse off? These issues are broadly discussed in Hess and Orphanides [1995,2001a,b]. Simply put, while citizens are not expected to gain by war, it is leaders that choose to enter wars, not citizens. In particular, in Hess and Orphanides [2001b], we argue that nondemocratic leaders engage in potentially beneficial appropriative conflict through their ability to enjoy the benefits from conflict while leaving their citizenry to face the costs of conflict. In contrast, while democratically elected leaders are not able to avoid the potential costs from war that the citizenry are faced with, they are further motivated by the desire to hold office and enjoy any office specific rents. Indeed, in Hess and Orphanides [1995,2001a,2001b] we demonstrate how such "wag the dog" motives for war can be sustained by rational voters. ${ }^{3}$

In this paper, I provide a lower bound estimate for the welfare costs of conflict by exploring only the forgone consumption from being mired in a world of conflict. Following the approach by Lucas (1987), I demonstrate how one can theoretically "price" the effect that war has on consumption's growth and volatility. Intuitively, these consumption growth costs from war would be avoided in a perpetually peaceful world, which allows us to calculate the equivalent variation of how much individuals would be willing to give up in order to live in a peaceful world.

It is worth noting that implicit in the methodology is the assumption that obviating conflict is possible. Further, the peaceful world I consider removes the effect of war from all participants. That is the cost estimates that I provide are not those from choosing a peaceful path when others have not (i.e., the costs of "turning the other cheek"). Rather, the cost estimates are an individual

\footnotetext{
${ }^{1}$ Mueller (1989) goes so far as to say that major war between modernized countries is not only unprofitable but heading towards extinction. Indeed, he conjectures that it will follow the progression of dueling and slavery: from objectionable, to unfashionable, and then finally to unthinkable. Howard (2000) takes a less sanguine perspective: "So although it is tempting to believe that as the international bourgeois community extends its influence a new and stable world order will gradually come into being, we would be unwise to expect anything of the kind [p. 113]."

${ }^{2}$ See Lau, Poutvaara and Wagener (2002) and Nordhaus (2002) for recent studies that examine particular facets of the cost of conflict. In particular, the former study examines the cost of the draft while the latter explores the government spending costs to the U.S. of a potential conflict with Iraq.

${ }^{3}$ See Garfinkel and Skaperdas (1996) for a deeper consideration of the economic appropriative motive for conflict.
} 
country's net economic benefit from a peaceful world.

The remainder of the paper is organized as follows. In Section 2 I present a theoretical measure for estimating the economic welfare costs of conflict. Sections 3 and 4 discuss the data sources and compute the empirical magnitudes of the welfare costs of conflict, respectively. I conclude in Section 5.

\section{Theory}

To construct the lower bound estimate of the cost of conflict, I adopt a technique first suggested by Lucas (1987) to estimate the potential gains from removing business cycles. ${ }^{4}$ Lucas' approach asks us to consider two consumption paths-the path where there is some positive probability of entering into adverse or beneficial states and a synthetic path where the probabilities of entering into such states are zero. Since Lucas is only concerned with business cycle effects, he does not allow the average rate of consumption growth to differ between these two welfare paths. ${ }^{5}$ By equating the two consumption paths, one can "price" the amount an individual would be willing to give up on an annual basis to attain the latter path-i.e., it's equivalent variation. Lucas' insight hinges on the observation that the average person (or representative agent) would be willing to permanently give up to some portion of their current consumption to reduce or eliminate the uncertainty or variance of consumption over their lifetime.

Formally, begin with a representative individual who lives in country $i$ with lifetime utility described by the following equation: ${ }^{6}$

\footnotetext{
${ }^{4}$ Using U.S. data from the post-war period, Lucas estimated that the certainty equivalent of completely eliminating the business cycle was trivial-averaging less than one-tenth of one percent of consumption growth. Further, an increase of this magnitude was only for a relatively large coefficient of risk aversion $(\rho=10)$. This type of measure has also been used in other contexts. For example, it can also be used to gauge the welfare costs of international risk sharing-see van Wincoop (1994) and Crucini and Hess (2000).

${ }^{5}$ Lucas (1987) also considers the case where the mean growth rate of consumption is allowed to change, though in calculations separate from those that measure the costs of business cycles. More generally, this approach can be used to price the effects from removing other events such as terrorism, earthquakes, floods, etc...

${ }^{6}$ Importantly, the analysis departs from Lucas' method in the following critical way: while Lucas models the log level of consumption as being subject to i.i.d. shocks around a constant trend, I adopt the more appealing specification of the log of consumption being subject to i.i.d. shocks around a stochastic trend. This has a number of benefits. First, it is wildly more consistent specification of the data - see the Supplemental Appendix. Second, a random walk specification is consistent with the permanent income hypothesis, which again has broad support in the data. Third, it makes the theoretical and empirical work more consistent. See the discussion in Obstfeld and Rogoff (1996, pp.
} 


$$
U_{i t}=E_{t}\left\{\sum_{s=t}^{\infty}(1+\theta)^{-(s-t)}\left[\frac{C_{i s}^{1-\rho}}{1-\rho}\right]\right\},
$$

where $C_{i s}=\left(1+\mu_{i}\right)^{s-t} \overline{C_{i}} \exp ^{\left[\epsilon_{i s}-\frac{1}{2} \sigma_{\epsilon_{i s}}^{2}\right]}, \Delta \epsilon_{i s}=v_{i s}$ is a normal, i.i.d. mean-zero shock with variance $\sigma_{i}^{2}, \sigma_{\epsilon_{i s}}^{2}=(s-t) \cdot \sigma_{i}^{2}, \mu_{i}$ is the growth rate of consumption, and $\overline{C_{i}}$ is the baseline level of consumption for country $i$ in period $t$. Using the fact that $\exp [1-\rho] \epsilon_{i s}$ is log-normally distributed, it follows that:

$$
E_{t}\left\{C_{i s}^{1-\rho}\right\}=\left(1+\mu_{i}\right)^{(1-\rho)(s-t)} \bar{C}_{i}^{1-\rho} \exp \left[-\left\{(1-\rho) \rho \sigma_{i}^{2} / 2\right\}(s-t)\right]
$$

Assuming that the following holds for all $i$ countries,

$$
\Phi_{i} \equiv(1+\theta)^{-1}\left(1+\mu_{i}\right)^{1-\rho} \exp -\left\{(1-\rho) \rho \sigma_{i}^{2} / 2\right\}<1
$$

and substituting (2) into (1), expected utility is as follows:

$$
U_{i t}=\left[\frac{\overline{C_{i}}{ }^{1-\rho}}{1-\rho}\right]\left[1-\Phi_{i}\right]^{-1} .
$$

Instead of a world without consumption uncertainty, as Lucas (1987) proposed for his measure of the welfare costs of business cycles, in this exercise I compare the expected welfare from each country remaining in its realized path of consumption, to another synthetic path of consumption where there is no state of war. In the two different consumption paths we have the observed world, where there is some observed probability of entering into a state of war, as well as the path where the effects of war are eliminated, denoted with *.7

$$
\text { 329-32). }
$$

${ }^{7}$ In neoclassical growth models, shocks, such as war, that affect the return on investment have short-run effects on the growth rate and the level of output but do not affect the steady-state rate of growth in the economy. Endogenous growth models allow distortionary taxes and (un)productive expenditure to affect the steady state growth rate. Bleaney, Gemmell and Kneller (2001) find evidence that strongly supports endogenous growth models. In particular, they find that when financed by a mixture of non-productive expenditures and and non-distortionary taxation, productive expenditures raise and distortionary taxes lower the growth rate. Also see Quah (1997) for a broader perspective on shortcomings of exogenous growth models. Moreover, the relationship between output and consumption will be affected by conflict, and it is the latter that is required in measuring welfare. Indeed, Braun and McGrattan (1993) argue that "output rises and private investment and consumption are crowded out" (p. 198) 
Some might question the validity of this counter-factual, that is, whether it is indeed possible to avoid conflict in all cases? Or, whether the ultimate cost of anticipating and preventing conflict is higher than the costs of engaging in war? ${ }^{8}$ While acknowledging these points, I believe that the essential question is meritorious: namely, what is the direct economic welfare loss from conflict? For even if current dispute resolution methods and institutions cannot avert all conflicts, pointing out the potential benefits may lead to the development of new institutions, or better enforcement and adherence to peaceful resolution, which can in turn lead some countries away from violence. By calculating this cost, I reveal the absolute minimum that people would be willing to pay in order to enjoy the economic benefits from peace.

For the time being let's put aside for now the estimation issues involved in creating a synthetic path of "peaceful" consumption. From a theoretical standpoint, however, both the average rate of consumption growth and the variance of consumption may differ in these two scenarios. For example, the growth rate of consumption could fall during (or after) war because a country's economic infrastructure has been damaged. In addition, economic volatility could rise during a war, as the fortunes of the various warring countries ebb and flow. To keep matters simple, denote the the mean and variance of the log-change of per-capita consumption in a peaceful world as $\mu_{i}^{*}$ and $\sigma_{i}^{2 *}$, respectively.

Formally, to "price" the amount that a representative household in each country would pay in order to obtain the peaceful path of consumption, we return to Lucas' methodology. In other words, I now solve for the amount of current consumption, $\tau_{i}^{*}$, that equates the expected welfare of remaining on the current path of consumption to one where consumption is devoid of conflict, namely:

$$
\left[\frac{\left(\left(1+\tau_{i}\right) \overline{C_{i}}\right)^{1-\rho} /(1-\rho)}{1-\Phi_{i}}\right]=\left[\frac{{\overline{C_{i}^{*}}}^{1-\rho} /(1-\rho)}{1-\Phi_{i}^{*}}\right]
$$

where $\Phi_{i}^{*} \equiv(1+\theta)^{-1}\left(1+\mu_{i}^{*}\right)^{1-\rho} \exp -\left\{(1-\rho) \rho \sigma_{i}^{2 *} / 2\right\}$.

The solution for $\tau_{i}$, assuming that $\overline{C_{i}}=\overline{C_{i}^{*}}$, is the following: ${ }^{9}$

during both World Wars for both the U.S. and U.K. See also McGrattan and Ohanian (1999).

${ }^{8}$ See Kaysen's (1990) review of Mueller (1989) for an insightful discussion of this point.

${ }^{9}$ Making the assumption that $\overline{C_{i}}=\overline{C_{i}^{*}}$ again places a lower bound on the welfare benefits from removing conflict from the world. In all likelihood, any reduction in military spending that follows from increased peace should lead to lower taxes and higher spending on private goods, with the associated improvement in labor supply and higher steady 


$$
\tau_{i}=\left[\frac{1-\Phi_{i}}{1-\Phi_{i}^{*}}\right]^{\frac{1}{1-\rho}}-1
$$

Again, $\tau_{i}$ is the fraction of current consumption that a representative individual in country $i$ would be willing to give up on a permanent basis in order to live in a world without conflict. To understand how potentially enhanced consumption growth and reduced consumption volatility can effect the economic welfare costs of conflict, first, define $\Delta \sigma_{i}^{2} \equiv\left(\sigma_{\mu_{i}}^{2 *}+\sigma_{u_{i}}^{2 *}\right)-\left(\sigma_{\mu_{i}}^{2}+\sigma_{u_{i}}^{2}\right)$ and $\Delta \mu_{i} \equiv \mu_{i}^{*}-\mu_{i}$. A log-linear approximation of expression (6) in the neighborhood of $\Delta \mu_{i}=\Delta \sigma_{i}^{2}=0$ yields: ${ }^{10}$

$$
\tau_{i}^{*} \approx\left[\frac{\Phi_{i}}{1-\Phi_{i}}\right] \cdot\left[-(\rho / 2) \Delta \sigma_{i}^{2}+\left(1+\mu_{i}\right)^{-1} \Delta \mu_{i}\right]
$$

Ceteris paribus, if a more peaceful world can deliver more growth and less volatility, each of these factors will raise the amount that a representative individual would pay in order to get rid of conflict.

In the following sections, the historical effect of conflict on the consumption growth path are estimated. In practical terms, I provide estimates of the change in each country's per-capita consumption growth rate and its variability if it were to move from its current path where wars occur to a path where they do not. This involves estimating parameters for $\mu_{i}, \mu_{i}^{*}, \sigma_{i}^{2}$, and $\sigma_{i}^{2 *}$. In this way, the value of removing these effects of conflict on the expected economic welfare from consumption can be priced.

It should be clear that what I advocate is a lower bound estimate on the true cost of conflict since many of the costs discussed earlier are not included in this calculation. The costs neglected are many: loss of life, loss of close personal friends or family, forced conscription, distributional costs, etc. Rather, by focusing only on the welfare costs of conflict stemming from consumption, a truly lower bound estimate of war's ultimate harm is obtained.

state level of consumption. For example, recent evidence in Ramey and Shapiro [1998] suggests that in post-war U.S. data, consumption and manufacturing productivity are negatively affected by exogenous military buildups.

${ }^{10}$ Although we provide the Taylor approximation in expression (7), all calculations below (Tables 4-6) are done using the exact solution, expression (6). 


\section{The Data}

This section begins with a description of the data. The economic data are obtained from the update to the Summers and Heston (1991) data set. To gauge the impact of conflict, both internal and external, on consumption's empirical moments, three main data sources are used. To measure internal conflict, I use the data set constructed by Gurr and Harff (1997). The external conflict data are from the International Crisis Behavior data set by Brecher, Wilkenfeld and Moser (1988, 1997) and the updated Correlates of War data by Small and Singer (1982). Both conflict data sets were used to construct the dummy variables for the eight types of conflict discussed below.

The data for internal conflicts were obtained from the State Failure Data Set compiled by a research team under the direction of Ted Robert Gurr of the University of Maryland and Barbara Harff of the U.S. Naval Academy, originally for use by the CIA. The data was originally assembled in 1994 and updated in 1997. The State Failure data divides internal conflict into four categories. First, ethnic conflict (ETHN) is defined as conflict between the government and national ethnic, religious, or other communal minorities seeking changes in their status. In order to be considered a war, more than 1000 individuals had to be mobilized and 1000 fatalities must have occurred during a given year. Second, genocide (GENO) includes the promotion, execution, and/or consent of sustained policies by governing elites or their agents that result in more than 1000 deaths per year of either a communal group or a politicized non-communal group (politicide). This differs from ethnic conflict in that victims counted are non-combatants. Third, revolution (REVO) is defined as conflict between the government and politically organized groups seeking to overthrow those in power. Groups include political parties, labor organizations, or parts of the regime itself. Once again, in order to be considered a war, more than 1000 individuals had to be mobilized and 1000 fatalities must have occurred per year. Finally, regime change (REGM) includes state collapse and shifts from democratic and authoritarian rule as defined by a shift of at least 3 points on the Freedom House polity scale. Further, the level of violence associated with the regime change must at minimum include armed violence in the capital (as in the case of violent coups). This measure does not include nonviolent transitions. ${ }^{11}$ In all, ETHN, GENO, REVO and REGM are dummy

\footnotetext{
${ }^{11}$ See Collier and Sambanis (2002) and the references therein for a broader description of the economic causes and consequences of civil wars.
} 
variables that take the value 1 if an internal conflict of that type takes place, and zero otherwise.

The data for external conflict were obtained from the International Crisis Behavior (ICB) project undertaken by Brecher, Wilkenfeld and Moser (1988) and Brecher and Wilkenfeld (1997), and includes the initiation or escalation of a conflict that warrants the highest level of severity. Also, from this data set, periods where a conflict continues can also be determined. They define external conflict (EXT), a trigger to a foreign policy crisis, as:

... a specific act, event or situational change which leads decision-makers to perceive a threat to basic values, time pressure for response and heightened probability of involvement in military hostilities. A trigger may be initiated by: an adversary state; a non-state actor; or a group of states (military alliance). It may be an environmental change; or it may be internally generated. Brecher, Wilkenfeld and Moser (1988) [p. $53]$

A foreign policy crisis with the highest intensity of violence, "full-scale war," was deemed a violent external conflict. ${ }^{12}$

External conflicts, both inter- and extra-state wars, that appear in the Correlates of War database, initiated by Small and Singer (1982), are used to determine whether a conflict is largescale or big (B). The Correlates of War data is helpful in this regard as these conflicts are required to have at least 1000 military casualties to be included in their data set. External conflicts that are not deemed "big", are deemed small (S). ${ }^{13}$ Both types of external conflict are disaggregated using the ICB data into home (H) and away (A) conflicts-conflicts which occur on the actor's home territory, and those that do not, respectively. In all, there are four types of external conflict: external big home (EXTBH), external big away (EXTBA), external small home (EXTSH), and external small away (EXTSA). Each type of external conflict is again coded as a dummy variables that take the value 1 if an internal conflict of that type takes place, and zero otherwise.

Finally, the economic data are from the Summers and Heston data set. I calculated log per-capita annual consumption growth rates for most countries from 1950 to 1992, although for

\footnotetext{
${ }^{12}$ This definition was similarly adopted in Blomberg, Hess and Thacker (2001), Hess and Orphanides (1995,2001a) and Blomberg and Hess (2002).

${ }^{13}$ A similar classification is used in Hess and Orphanides (2001a) for the United States.
} 
many countries the data does not begin until 1960. Demographic and descriptive data are taken from the World Bank's Social Indicators and Fixed Factors data set as well as various sources described in Sala-i-Martin (1997) - see Data Appendix.

\section{Evidence}

In the following sub-sections, I quantify the impact of conflict on consumption's mean growth and volatility. Sub-section 4.1 provides some summary statistics on conflict on a country-bycountry basis. In sub-section 4.2 I quantify the effect that conflict has on consumption's statistical moments. Finally, in sub-section 4.3 I compute the welfare costs of conflict as well as demonstrate the robustness of these computations to changes in the methods for estimating the effect of conflict on consumption.

\subsection{Empirical Regularities}

This section begins by examining the average incidence of conflict by type. I consider eight different specifications for conflict: large external wars fought on home territory $(E X T B H)$, small external wars fought on home territory $(E X T S H)$, large external wars fought away $(E X T B A)$, small external wars fought away (EXTSA), genocides $(G E N O)$, ethnic conflicts (ETHN), abrupt and disruptive regime changes $(R E G M)$, and revolutionary wars $(R E V)$. Table 1 reports the fraction of time that countries (1) engaged in at least one conflict and (2) had more than five observations on consumption growth spent in different types of conflict during the sample period (1960-92). The Data Appendix reports those countries that did not have either internal or external conflicts, as defined by the data sets described above, or for whom there was not consumption data. ${ }^{14}$ Table 1 raises several questions about the way in which conflicts are coded. For example, according to the table, the former U.S.S.R. did not engage in conflicts from 1960 to 1992. In light of recent events, the Soviet occupation of Afghanistan (1979-88) immediately springs to mind. The reason behind

\footnotetext{
${ }^{14}$ Note that Summers and Heston (1992) data are not available for a number of extremely poor countries such as Afghanistan. Since many of these countries have been devoured by conflict, the omission of these countries is likely to bias downward even further my admittedly lower bound cost of conflict. See the Data Appendix for the omitted countries.
} 
Table 1: Fraction (\%)of Time Spent in Conflict by Type

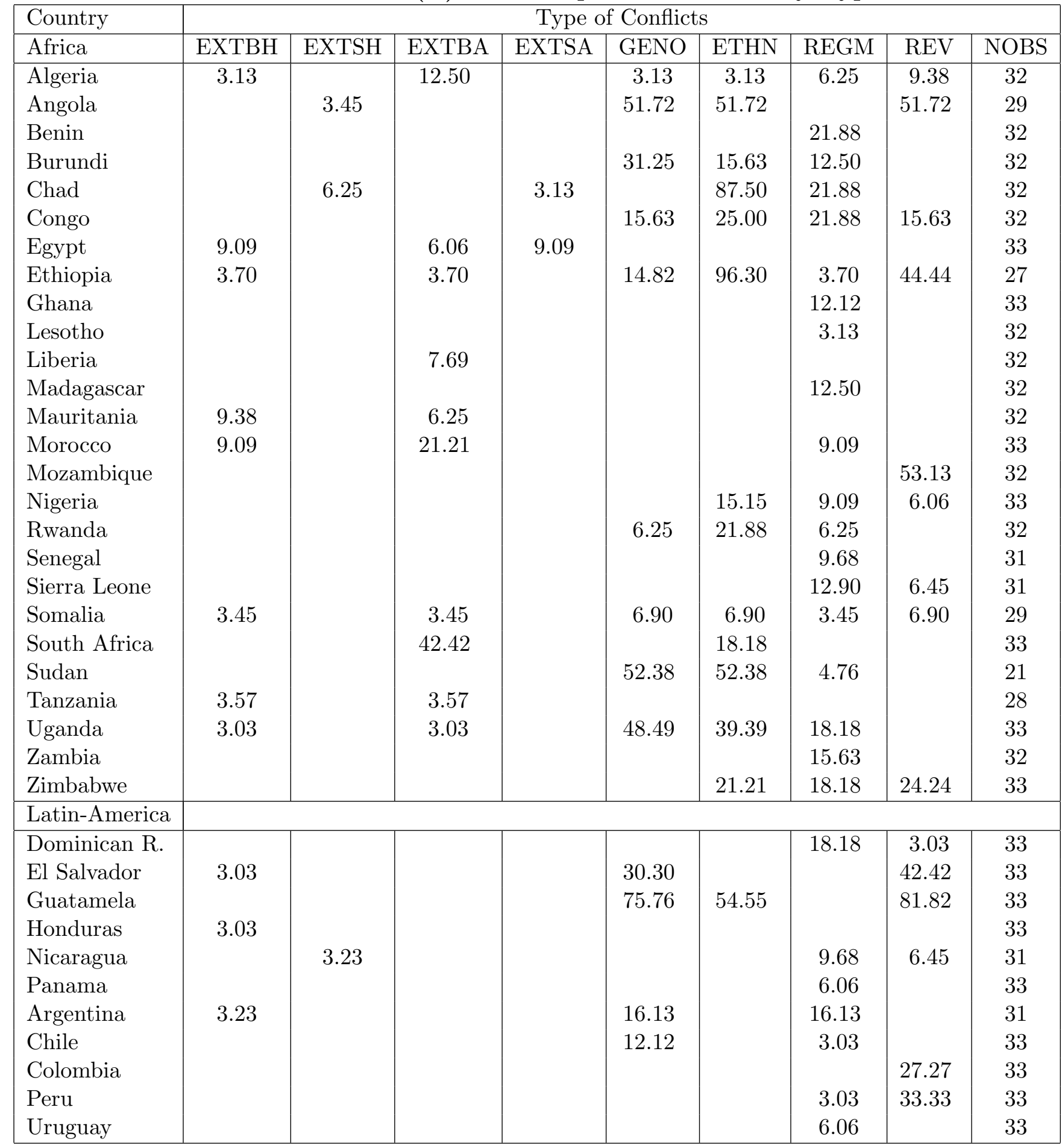

Note: Continued. 
Table 1 (Continued): Fraction (\%) of Time Spent in Conflict by Type

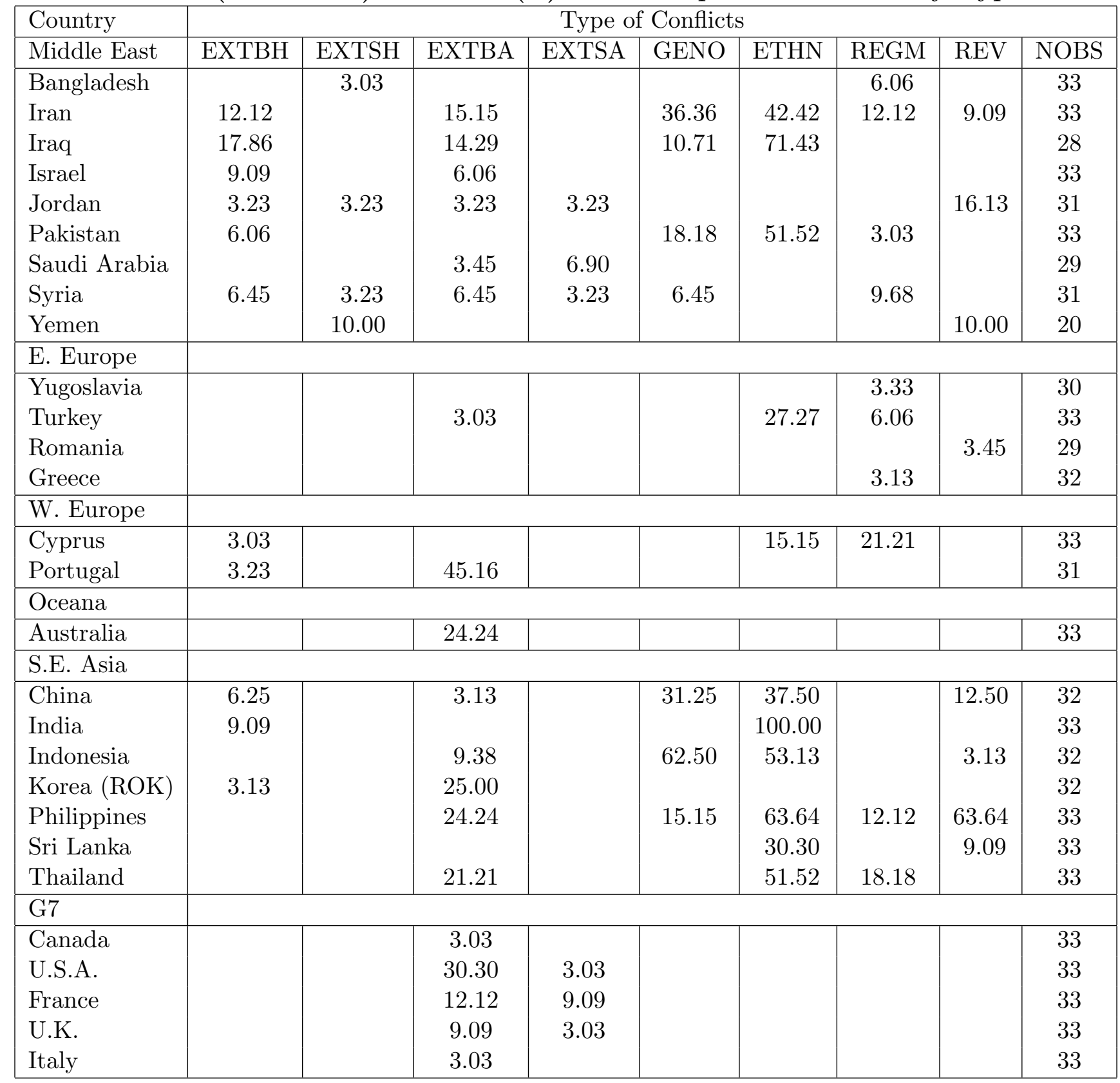

Note: See Data Appendix for data descriptions. Each cell contains the fraction of time a country spent engaged in a given type of conflict during the sample period for countries with more than five observation on consumption growth. 
this apparent oversight is that the severity of violence did not reach "full scale war" but rather "severe clashes." However, rather than actively amend the data, which could ultimately only cast suspicion on the results, I accept the coding by the various data sources as definitive, despite some such occurrences. Laos and Kuwait provide additional examples of well-known "conflicts" that do not appear in Table 1. Internal war data do, in fact, indicate that Laos was in a sustained state of ethnic and revolutionary conflict throughout the 1960's and 1970's. The availability of consumption growth data for Laos (1985-1991) is the limiting factor. Since more than five years of consumption growth data are available, Laos is included in the sample. However, because the conflict data do not overlap the consumption growth data no conflicts are recorded during this period. Similarly the Gulf War (1990) is recorded as a full scale war but Kuwait consumption growth is only available until 1989. Again, such an omission gives strength to the argument that the welfare cost measure is a lower-bound estimate.

\subsection{Estimation}

In developing a baseline specification for a country's per-capita consumption growth, and how conflict might affect it, the simple permanent income hypothesis $(\mathrm{PIH})$ provides a very reasonable starting point. ${ }^{15}$ According to the PIH, the change in consumption should be unforecastable, so that information from prior periods is not helpful in predicting future consumption growth. Of course, current information such as a conflict would affect consumption growth and not violate this basic tenet of the PIH. Furthermore, the adoption of this empirical approach is consistent with the theoretical treatment of consumption innovations in Section 2. ${ }^{16}$ Hence, the baseline specification is:

$$
\Delta \log \left(c_{i t}\right)=\alpha_{1} \cdot I N I T_{i t}+\alpha_{2} \cdot C O N T_{i t}+\alpha_{3} \cdot C O M P L_{i t}+I_{i}+T_{t}+e_{i t},
$$

\footnotetext{
${ }^{15}$ There is also strong statistical evidence to support modeling the effect of conflict on consumption in growth rates rather than in log-levels. See the Supplemental Appendix.

${ }^{16}$ The PIH, however, does have its limitations: it is derived from a quadratic utility specification so that it omits a precautionary savings motive and it ignores the fact that households might be borrowing constrained. While these criticisms are likely to be important in micro-studies of household consumption behavior, the general consensus is that they are not "economically" significant in macroeconomic studies of consumption behavior. Indeed, Nelson (1987) argues that allowing for lagged consumption and income effects effects in U.S. data only generates a very modest $R^{2}$ of only about .07 .
} 
where again $\Delta \log \left(c_{i t}\right)$ is the log-difference of per-capita consumption for country $i$ at time $t, I_{i}$ and $T_{t}$ are estimated individual and time fixed effects, respectively. For the conflict variables, INIT is the initiation or escalation of a conflict, CONT is the continuation of a conflict other than its initial year, and $C O M P L$ refers to the completion of a conflict. More formally, $W_{i t}=1$ if a war-conflict type event occurs for country $i$ in period $t . I N I T_{i t}=1$ if $\Delta W_{i t}>0, C O N T_{i t}=1$ if $W_{i t}=1$ and $\Delta W_{i t}=0$, and $C O M P L=1$ if $\Delta W_{i t}<0 .{ }^{17}$

The empirical specification embodied in equation (8) allows for a wide range of dynamics in how conflict affects consumption growth. For example, the initiation of a conflict will lead to a temporary effect on a country's consumption growth rate, and a permanent effect on the log-level of consumption, as long as $\alpha_{1}$, the coefficient on INIT, differs from zero. Moreover, separately allowing for conflict continuations to affect consumption is meant to capture the possibility that conflicts that last longer than a year, CONT, may lead to different expected consumption paths than if the conflict was short and lasted one period. Finally, there remains the possibility that any effects of conflict on consumption growth may reverse themselves once the conflict has reached completion. Such rebound effects are proxied by including COMPL in the specification. Taken together, the empirical specification in equation (8) allows for initial effects of conflict on consumption, duration effects of conflict on consumption, and the reversal of these forces upon the completion of a conflict. However, below in Table 5, I explore some changes in the specification to examine the robustness of our lower bound estimates of the welfare costs of conflict. ${ }^{18}$

\footnotetext{
${ }^{17}$ Note that the dummy variables embody an implicit structure in the evolution in the observed states of conflict. For instance, for a given type of conflict (e.g. Big Wars at Home), let $s_{1 t}=1$ if peace at time $t$ and zero otherwise, let $s_{2 t}=1$ if INIT at time $t$ and zero otherwise, let $s_{3 t}=1$ if CONT at time $t$ and zero otherwise, and let $s_{4 t}=1$ if COMPL at time $t$ and zero otherwise. Then the obsreved states follow a restricted transition matrix according to:

$$
\left[\begin{array}{l}
s_{1 t} \\
s_{2 t} \\
s_{3 t} \\
s_{4 t}
\end{array}\right]=\left[\begin{array}{cccc}
\phi_{11} & 0 & 0 & \phi_{14} \\
\phi_{21} & 0 & 0 & \phi_{24} \\
0 & \phi_{32} & \phi_{33} & 0 \\
0 & \phi_{42} & \phi_{43} & 0
\end{array}\right]\left[\begin{array}{l}
s_{1 t-1} \\
s_{2 t-1} \\
s_{3 t-1} \\
s_{4 t-1}
\end{array}\right]
$$

The transition matrix indicates that the state of peace can only be followed by peace or an initiation. An initiation can only be followed by a continution of conflict or its completion. The continuation of a conflict can only be followed by a further continution or a completion of the conflict. And the completion of a conflict can only be followed by peace or by the initiation of a new conflict. Note further that $\phi_{11}=1-\phi_{21}, \phi_{14}=1-\phi_{24}, \phi_{32}=1-\phi_{42}$, and $\phi_{33}=1-\phi_{43}$. Following standard procedures, one can estimate the steady state fractions of peace and conflict per-country. Unfortunately, the size of the transition matrix becomes too unwieldy to estimate for eight separate types of conflict in order to obtain these steady-state vectors. Nevertheless, this study compares the growth and volatility of consumption under the observed historically observed fraction of peace and conflict (rather than the steady state fractions), with the growth and volatility of consumption when the only observed state is that of peace.

${ }^{18}$ Another potential source of error in the specification is the possible dynamic nature of the relationship being estimated. Although this would not bias the estimated coefficients of the impact of conflict on growth, the estimated
} 
Table 2 reports the estimates of equation (8) using data for all 147 countries for which there is consumption data-see Data Appendix. ${ }^{19}$ The estimated standard errors of the coefficients, reported in parentheses, are robust to heteroskedasticity and serial correlation of unknown form-see Newey and West (1987). The first column of Table 2 displays the average effect of the initiation of conflict on a country's per-capita consumption growth rate, controlling for fixed individual country and time effects. All eight individual types of conflict under consideration are included in the regression. ${ }^{20}$ Columns two and three of Table 2 display the average effect of continuation and completion of conflict, respectively. I report in the last three columns results from a parsimonious specification that includes only the variables that were statistically significant below the .1 level when all of the coefficients are estimated jointly. Importantly, the effects reported in columns four through six are used in the welfare calculations presented below. Also, Table 2 reports the adjusted $R^{2}$, sum of squared residuals, and the number of observations.

Taking the first column as an example, the coefficient on EXTBH is negative and statistically significant at below the .05 level. This implies that the initiation or escalation of a large external war on a nation's home territory lowers annual per-capita consumption growth by 4.4 percentage points. One can also interpret this finding as that consumption growth would be more than 4 percentage points higher than observed for the year that a country was involved in the initiation or escalation of a large external home war-provided the country had somehow managed to avoid conflict.

All of the statistically significant coefficients in Table 2 have the expected (negative) sign,

standard errors of the coefficients would be biased. In fact, simple least squares would provide a consistent but inefficient estimate of the coefficients, though, as mentioned, a non-robust estimate of the standard errors would be biased. The latter is not a problem in the results below as the estimated standard errors were calculated as in Newey-West, where I have corrected for heteroskedasticity of unknown form and allow for serial correlation of up to a fourth order moving average. Arellano and Bond (1991) suggest an alternative way to explicitly estimate a dynamic panel data model with fixed effects by instrumenting a version of equation (8) which also includes a lagged dependent variable. Note that in comparing the Arellano and Bond (1991) estimates of the mean effect of war (not shown) to those estimates in Table 2, the pattern of significance is identical and the coefficients are very similar in magnitude.

${ }^{19}$ That is, the regressions are estimated with data for 62 countries that faced some type of conflict and 85 countries that did not.

${ }^{20}$ The findings in Table 1 suggest a positive correlation between certain types of conflicts (e.g. genocide and ethnic conflicts. The average correlation between genocide and ethnic conflicts across countries with at least one genocide is 0.42. The average correlation between genocide and ethnic conflicts for countries with at least one ethnic conflict is 0.31. Similarly, the average correlations for regime changes and revolutions are only 0.10 and 0.17 . However, this does not materially affect the results below. For example, when I experimented with a variable that combined a number of these conflicts to ensure that multicollinearity was not a problem, the pattern of significance was unchanged and the magnitudes remained similar. 
Table 2: Estimated Effect of Conflict on Real Per-Capita Consumption Growth

\begin{tabular}{|l|c|c|c|c|c|c|}
\hline & \multicolumn{3}{|c|}{ Individual Specification } & \multicolumn{3}{c|}{ Joint Specification } \\
\hline & INIT & CONT & COMPL & INIT & CONT & COMPL \\
\hline EXTBH & $-4.37^{* *}$ & $-10.47^{* *}$ & $-4.49^{* *}$ & $-4.59^{* *}$ & $-10.97^{* *}$ & $-3.36^{*}$ \\
& $(2.18)$ & $(4.71)$ & $(1.96)$ & $(1.98)$ & $(4.92)$ & $(1.82)$ \\
EXTSH & -8.83 & 0.17 & -3.54 & & & \\
& $(6.19)$ & $(1.95)$ & $(6.11)$ & & & \\
EXTBA & $-4.06^{* * *}$ & 0.45 & -0.90 & $-2.31^{*}$ & & \\
& $(1.49)$ & $(0.76)$ & $(1.20)$ & $(1.23)$ & & $-3.79^{* *}$ \\
EXTSA & 0.97 & -0.57 & $-4.58^{* * *}$ & & & \\
& $(1.72$ & $(0.82)$ & $(1.70)$ & & & \\
GENO & $-5.96^{* *}$ & -0.20 & 0.01 & $-5.78^{* *}$ & & \\
& $(2.65)$ & $(1.13)$ & $(2.89)$ & $(2.40)$ & & \\
ETHN & 0.01 & 0.53 & 0.72 & & & \\
& $(2.04)$ & $(0.75)$ & $(4.69)$ & & & \\
$R E G M$ & -2.31 & $-3.74^{* * *}$ & -0.28 & & & \\
& $(1.83)$ & $(1.02)$ & $(2.31)$ & & & \\
$R E V$ & -3.41 & -1.18 & 0.69 & & & \\
& $(2.69)$ & $(0.94)$ & $(5.35)$ & & & \\
\hline$R^{2}$ & 0.05 & 0.04 & 0.04 & & & \\
$\sigma^{2}$ & 8.79 & 8.82 & 8.83 & & & \\
NOBS & 4273 & 4273 & 4273 & & & \\
\hline
\end{tabular}

Notes: See Data Appendix for definitions. The first three columns of results report the estimated effects from equation (8), when the initiation and escalation of a conflict (INIT), the continuation of a conflict (CONT) and the completion of a conflict (COMPL) are estimated separately. The results in the final three columns are for when all three measures of conflict are included simultaneously and only those coefficients that were significantly different from zero at below the .1 level were retained in the specification. The estimated standard errors, are robust to heteroskedasticity and serial correlation of unknown form-see Newey and West (1987). ${ }^{*},{ }^{* *},{ }^{* * *}$ indicate statistical significance at below the .1, .05 and .01 levels, respectively. 
indicating that conflict does indeed have an adverse affect on consumption growth. It may not be any more surprising that the initiation, continuation, and completion of a large external war on one's home territory (EXTBH \& INIT, EXTBH \& CONT, EXTBH \& COMPL) are all statistically significant in the joint specification. Perhaps more interesting is that the impact of such a conflict on annual per-capita consumption growth, provided it lasts more than a single year, is a cumulative loss of nearly 20 (18.92) percentage points. Continuation alone costs consumers nearly 11 percent per year in terms of consumption growth. The initiation of genocides and large external wars fought away (GENO \& INIT, EXTBA \& INIT), the continuation of regime changes past their initiation (REGM \& CONT), and the completion of small external wars fought away (EXTSA \& COMPL) are also significant in reducing consumption growth below what it would otherwise have been in a state of peace. ${ }^{21}$

From the results in the last three columns of Table 2, one can construct a "synthetic" growth rate were an economy to be perpetually at peace as follows. From the estimated, fitted values of equation (8), each country's "peaceful" growth rate at time $t$ is just $\left.\Delta \widehat{\log (} c_{i t}\right)^{*} \equiv X_{i t}^{*}=$ $\hat{I}_{i}+\hat{T}_{t}+\hat{e}_{i t}$. Averaging this yields each country's peaceful growth rate of per-capita consumption, $\widehat{\mu}_{i}^{*}=(1 / T) \sum_{t=1}^{T} X_{i t}^{*}$. Interestingly, by netting out the effect of wars on consumption growth from expression (8), the estimation procedure allows the country's estimated individual effects as well as the aggregate time effects to change. In essence, $\widehat{\mu}_{i}^{*}$ confounds both effects so that even countries who do not experience war may be beneficially impacted if aggregate consumption growth strengthens because other countries become more peaceful. To separate out these two effects, define $\widehat{\mu}_{i}^{*^{\prime}}=\hat{I}_{i}+\sum_{t=1}^{T} \hat{T}_{t}^{\prime}$ where $\hat{T}_{t}^{\prime}$ were obtained from a constrained form of expression (8) where $\alpha_{1}=\alpha_{2}=\alpha_{3}=0 .{ }^{22}$ Simply put, $\widehat{\mu}_{i}^{*^{\prime}}$ is the estimate of the $i^{\text {th }}$ country's consumption growth rate if it were only to enjoy the local-direct benefits from peace, while $\widehat{\mu}_{i}^{*}$ includes both the local-direct and global benefits of consumption growth from peace. ${ }^{23}$

\footnotetext{
${ }^{21}$ These results concur with Caplan (2001) who finds that real output growth falls substantially during domestic wars. However, in contrast, Caplan also finds that real output growth rises slightly during foreign wars. I believe that this may be due to his use of a smaller data set (66 countries) and failure to parse out the initiation, continuation, and conclusion of internal and external conflicts as well as the various types of internal conflict.

${ }^{22}$ Namely, the $\hat{T}_{t}^{\prime}$ are estimated from the regression: $\Delta \log \left(c_{i t}\right)=I_{i}+T_{t}^{\prime}+$ error.

${ }^{23}$ In an important contribution, Alesina and Spolaore (2000) demonstrate that this global "peace dividend" may not materialize in a world where the number and size of nations is endogenous, and the per-capita costs of defense spending decline with the country size.
} 
Turning now to the impact of conflict on economic volatility, Table 3 presents the individually and jointly estimated effects of eliminating different types of conflict on the variance of mean-adjusted consumption growth. The construction of a synthetic measure of the volatility (either standard deviation or variance) of consumption during peace involves two steps: estimating the mean squared growth in consumption during peace and the squared mean growth in consumption during peace. Fortunately, the latter has been calculated, $\left(\widehat{\mu}_{i}^{*}\right)^{2}$. Hence, to insure that this volatility measure does not become negative, I adopt the following specification for the squared growth of per-capita consumption.

$$
\left|X_{i t}^{*}\right|^{2}=\exp \left\{2 \cdot\left[\delta_{1} \cdot I N I T_{i t}+\delta_{2} \cdot C O N T_{i t}+\delta_{3} \cdot C O M P L_{i t}+I_{i}+T_{t}+u_{i t}\right]\right\}
$$

According to this exponential specification, the squared change in per-capita consumption growth will always be positive, and one can estimate the fixed individual and time effects and the effect of conflict on volatility using non-linear least squares. A more appealing approach, however, is to take natural logs of both sides of (9) so that one can estimate these same crucial parameters using least squares, namely:

$$
\log \left(\left|X_{i t}^{*}\right|\right)=\delta_{1} I N I T_{i t}+\delta_{2} \cdot C O N T_{i t}+\delta_{3} \cdot C O M P L_{i t}+I_{i}+T_{t}+u_{i t}
$$

Notice that one can come up with a reasonable measure of the effect of conflict on consumption volatility by estimating the parameters of the transformed model.

As in Table 2, the first three columns of Table 3 display results from the initiation, continuation, and completion of conflict estimated individually, and the last three columns present a parsimonious joint specification which excludes insignificant regressors. Again taking column 1 as an example, we find that the coefficient on $G E N O$ is positive and statistically significant at the .01 level. This implies that the volatility of consumption growth is higher during the initiation of genocides. The adjusted $R^{2}(0.20)$ indicates that the specification explains a larger fraction of consumption growth variance than was the case for consumption growth displayed in Table 2 .

Several noteworthy distinctions separate Table 3 from Table 2. Among the statistically 
Table 3: Estimated Effect of Conflict on Real Per-Capita Consumption Volatility

\begin{tabular}{|c|c|c|c|c|c|c|}
\hline & \multicolumn{3}{|c|}{ Individual Specification } & \multicolumn{3}{|c|}{ Joint Specification } \\
\hline & INIT & CONT & COMPL & INIT & CONT & COMPL \\
\hline$E X T B H$ & $\begin{array}{c}0.26 \\
(0.20)\end{array}$ & $\begin{array}{c}-0.18 \\
(0.29)\end{array}$ & $\begin{array}{l}0.41^{* *} \\
(0.17)\end{array}$ & & & \\
\hline EXTSH & $\begin{array}{c}0.34 \\
(0.38)\end{array}$ & $\begin{array}{c}-4.96^{* * *} \\
(0.26)\end{array}$ & $\begin{array}{c}0.21 \\
(0.36)\end{array}$ & & $\begin{array}{c}-4.92^{* * *} \\
(0.26)\end{array}$ & \\
\hline$E X T B A$ & $\begin{array}{c}0.24 \\
(0.16)\end{array}$ & $\begin{array}{c}-0.15 \\
(0.12)\end{array}$ & $\begin{array}{c}0.09 \\
(0.16)\end{array}$ & & & \\
\hline$E X T S A$ & $\begin{array}{c}0.07 \\
(0.30)\end{array}$ & $\begin{array}{c}-0.08 \\
(0.19)\end{array}$ & $\begin{array}{c}-0.57 \\
(0.30)\end{array}$ & & & \\
\hline GENO & $\begin{array}{l}0.70^{* * *} \\
(0.22)\end{array}$ & $\begin{array}{c}0.09 \\
(0.14)\end{array}$ & $\begin{array}{c}-0.07 \\
(0.24)\end{array}$ & $\begin{array}{l}0.75^{* * *} \\
(0.20)\end{array}$ & & \\
\hline$E T H N$ & $\begin{array}{c}-0.10 \\
(0.21)\end{array}$ & $\begin{array}{c}0.10 \\
(0.10)\end{array}$ & $\begin{array}{l}0.85^{* * *} \\
(0.26)\end{array}$ & & & $\begin{array}{l}0.80^{* * *} \\
(0.25)\end{array}$ \\
\hline REGM & $\begin{array}{c}0.39^{* *} \\
(0.18)\end{array}$ & $\begin{array}{l}0.31^{* *} \\
(0.14)\end{array}$ & $\begin{array}{c}-0.11 \\
(0.17)\end{array}$ & $\begin{array}{l}0.40^{* *} \\
(0.18)\end{array}$ & $\begin{array}{c}0.27^{* *} \\
(0.13)\end{array}$ & \\
\hline$R E V$ & $\begin{array}{c}0.21 \\
(0.28)\end{array}$ & $\begin{array}{c}0.05 \\
(0.16)\end{array}$ & $\begin{array}{c}0.23 \\
(0.29)\end{array}$ & & & \\
\hline$R^{2}$ & 0.20 & 0.20 & 0.20 & & & 0.20 \\
\hline$\sigma^{2}$ & 1.16 & 1.16 & 1.16 & & & 1.16 \\
\hline$N O B S$ & 4273 & 4273 & 4273 & & & 4273 \\
\hline
\end{tabular}

Notes: See Table 2. The first three columns of results report the estimated effects from equation (10), when the initiation and escalation of a conflict (INIT), the continuation of a conflict (CONT) and the completion of a conflict (COMPL) are estimated separately. The results in the final three columns are for when all three measures of conflict are included simultaneously and only those coefficients that were significantly different from zero at below the .1 level were retained in the specification. 
significant coefficients in the joint volatility specification (GENO \& INIT, REGM \& INIT, EXTSH \& CONT, REGM \& CONT, and ETHN \& COMPL), only the continuation of regime changes also affected the average level of consumption growth. Further, conflicts do not uniformly increase volatility in the same manner in which they were found to lower consumption growth. The continuation of small external home wars decreases volatility. In fact, the estimated decrease in volatility due to EXTSH \& CONT is much greater than the largest increase (ETHN \& COMPL).

Using the estimates from equation (10) presented in the last three columns of Table 3, one can calculate the predicted squared growth of peaceful consumption growth using equation (9) as $\left[\widehat{X}_{i t}^{*}\right]^{2}=\exp \left\{2 \cdot\left[\hat{I}_{i}+\hat{T}_{t}+\hat{u}_{i t}\right]\right\}$. From this expression, one can calculate the variance of peaceful consumption growth, $\widehat{\sigma}_{i}^{2 *}=(1 / T) \sum_{t=1}^{T}\left[\widehat{X}_{i t}^{*}\right]^{2}-\left[\widehat{\mu}_{i}^{*}\right]^{2}$. Again, as in the case for mean consumption growth, $\widehat{\sigma}_{i}^{2 *}$ combines both the country's individual growth improvement with the indirect benefit from faster world consumption growth in a peaceful world. Hence, following the earlier definition of $\widehat{\mu}_{i}^{*^{\prime}}$, define $\widehat{\sigma}_{i}^{2 *^{\prime}}$ the global volatility of consumption is assumed unchanged if the world were to move to peace. ${ }^{24}$

Taken together, Tables 2 and 3 lead to one obvious conclusion: very different types of conflict affect the level and volatility of consumption growth. Large external home wars, the initiation of large conflicts with foreign countries, the continuation of disruptive regime changes, and the completion of small external foreign conflicts reduce average per-capita consumption growth. The initiation of genocides and disruptive regime changes, the continuation of disruptive regime changes, and the completion of ethnic wars increase the volatility of per-capita consumption growth while the continuation of small external foreign wars decrease its volatility.

\subsection{Welfare Calculations}

To implement the welfare calculations embodied in expression (6), parameter values for the discount rate $(\theta)$ and the coefficient of relative risk aversion $(\rho)$ must be provided, in addition to the consumption growth and volatility measures calculated from findings in Tables 2 and 3 . Columns one

\footnotetext{
${ }^{24}$ More formally, this is calculated in 2 steps. First calculate $\left[X_{i t}^{*}\right]^{\prime 2}=\exp \left\{2 \cdot\left[\hat{I}_{i}+\hat{T}_{t}^{\prime}+\hat{u}_{i t}\right]\right\}$, where $\hat{T}_{t}^{\prime}$ is obtained from the following regression: $\log \left(\left|X_{i t}^{*}\right|\right)=I_{i}+T_{t}+$ error. Second, calculate $\widehat{\sigma}_{i}^{2 *^{\prime}}=(1 / T) \sum_{t=1}^{T}\left[X_{i t}^{*}\right]^{\prime 2}-\left[\widehat{\mu}_{i}^{*^{\prime}}\right]^{2}$.
} 
through six of Table 4 provide these latter measures: namely, they present on a country-by-country basis the observed and constructed economic characteristics required for implementing the welfare calculations of conflict. Columns seven and eight contain the estimated welfare cost of conflict for the local-direct and global benefits of peace. The last two columns of Table 4 provide an indication of the sensitivity of these welfare calculations to changes in $\theta$ and $\rho$.

Columns one and three of Table 4 present the observed mean growth rates of consumption per-person, $\widehat{\mu}_{i}$, and the counterfactual or synthetic mean growth rate of consumption per-person growth that has been adjusted to remove the impact of conflict, $\widehat{\mu}_{i}^{*}$. We also report in column two the "synthetic" peaceful growth of consumption when the potential global benefit from reduced conflict is removed, $\widehat{\mu}_{i}^{*^{\prime}}$. Columns four and six present the observed standard deviation of the growth of consumption per-person, $\widehat{\sigma}_{i}^{2}$, and the variance of consumption growth adjusted to remove the effect of conflict, $\widehat{\sigma}_{i}^{2 *}$. Again, column five reports the "synthetic" peaceful standard deviation of consumption when the potential global benefit from reduced conflict is removed, $\left(\widehat{\sigma}_{i}^{*^{\prime}}\right)$. To reiterate, while the empirical specifications (8) and (10) impose the restriction that a given type of conflict has the same impact on each country for a given year, countries will have differing growth and volatility benefits from peace based on the types of conflicts in their observed data as well as the frequency with which they were in conflict.

The final step in implementing the welfare calculation, (6), is to specify values for $\theta$ and $\rho$. Clearly, changes in $\theta$ and $\rho$ will affect $\tau_{i}$. Four important issues in the selection of these parameters should be kept in mind. First, the parameter values should be plausible. Second, the parameters should be such that $\Phi_{i}<1$ and $\Phi_{i}^{*}<1$ for all countries - see expression (3). Third, the parameter values selected should be suggestive of a lower bound for $\tau_{i}$. Fourth, the reader should get an indication of the robustness of $\tau_{i}$ to changes in the values chosen for $\theta$ and $\rho$.

Columns 7 and 8 of Table 4 provide results for the welfare measures using $\theta=.08$ and $\rho=2$. These values were chosen for the following reasons, based on the criteria just discussed. First, these parameter values are certainly plausible, even though $\theta$ looks a bit high and $\rho$ looks a bit low. Second, for all countries, $\Phi_{i}<1$ and $\Phi_{i}^{*}<1$ when evaluated at these values of $\theta$ and $\rho$. Third, and most importantly, these parameters provide a relatively robust lower bound for the 
Table 4: Welfare Calculations

\begin{tabular}{|c|c|c|c|c|c|c|c|c|c|c|}
\hline & \multicolumn{3}{|c|}{ Growth } & \multicolumn{3}{|c|}{ Volatility } & \multicolumn{2}{|c|}{ Cost } & \multicolumn{2}{|c|}{ Elasticity } \\
\hline Country & $\hat{\mu}_{i}$ & $\hat{\mu}_{i}^{*^{\prime}}$ & $\hat{\mu}_{i}^{*}$ & $\hat{\sigma}_{i}$ & $\hat{\sigma}_{i}^{*^{\prime}}$ & $\hat{\sigma}_{i}^{*}$ & $\tau_{i}^{*^{\prime}}$ & $\tau_{i}^{*}$ & $\epsilon_{\tau_{i}^{*} \rho}$ & $\epsilon_{\tau_{i}^{*} \theta}$ \\
\hline \multicolumn{11}{|c|}{ Africa } \\
\hline Algeria & 1.22 & 1.90 & 1.97 & 14.91 & 10.09 & 10.20 & 26.91 & 27.67 & 0.99 & -1.15 \\
\hline Angola & -2.82 & -2.62 & -2.54 & 12.86 & 7.85 & 7.86 & 38.18 & 40.49 & 3.82 & -2.36 \\
\hline Benin & 0.10 & 0.65 & 0.73 & 6.64 & 6.62 & 6.71 & 7.18 & 8.02 & 0.06 & -1.04 \\
\hline Burundi & -0.96 & -0.27 & -0.19 & 10.83 & 10.25 & 10.36 & 14.24 & 15.18 & 0.97 & -1.37 \\
\hline Chad & -1.58 & -0.80 & -0.73 & 14.67 & 13.96 & 14.11 & 24.51 & 25.35 & 2.40 & -1.91 \\
\hline Congo & -1.11 & -0.09 & -0.01 & 14.24 & 12.41 & 12.55 & 32.26 & 33.18 & 1.84 & -1.67 \\
\hline Egypt & 2.47 & 3.68 & 3.75 & 4.38 & 4.63 & 4.67 & 10.94 & 11.59 & -0.60 & -0.78 \\
\hline Ethiopia & 0.28 & 0.87 & 0.95 & 3.44 & 3.66 & 3.69 & 7.02 & 7.91 & -0.14 & -0.98 \\
\hline Ghana & 0.07 & 0.39 & 0.46 & 10.17 & 9.88 & 9.99 & 5.40 & 6.18 & 0.47 & -1.14 \\
\hline Lesotho & 1.90 & 1.90 & 1.98 & 9.77 & 9.57 & 9.66 & 0.43 & 1.05 & 0.09 & -0.90 \\
\hline Liberia & -0.22 & -0.13 & -0.05 & 12.39 & 12.37 & 12.50 & 1.52 & 2.26 & 0.65 & -1.28 \\
\hline Madagascar & -2.51 & -2.18 & -2.10 & 4.97 & 4.87 & 4.92 & 6.89 & 8.33 & 1.14 & -1.55 \\
\hline Mauritania & 0.34 & 1.35 & 1.42 & 10.75 & 10.54 & 10.65 & 14.58 & 15.30 & 0.28 & -1.11 \\
\hline Morocco & 2.64 & 3.97 & 4.05 & 6.25 & 6.34 & 6.41 & 12.16 & 12.77 & -0.58 & -0.78 \\
\hline Nigeria & 1.48 & 1.69 & 1.77 & 13.94 & 12.90 & 13.04 & 6.52 & 7.04 & 0.80 & -1.06 \\
\hline Rwanda & 0.33 & 0.62 & 0.70 & 9.67 & 9.33 & 9.43 & 4.82 & 5.60 & 0.37 & -1.08 \\
\hline Senegal & 0.82 & 1.05 & 1.13 & 5.45 & 5.37 & 5.43 & 2.72 & 3.52 & -0.13 & -0.94 \\
\hline Sierra Leone & -0.03 & 0.20 & 0.27 & 6.73 & 6.45 & 6.52 & 3.51 & 4.41 & 0.24 & -1.06 \\
\hline Somalia & -1.48 & -0.93 & -0.85 & 19.85 & 20.05 & 20.26 & 21.01 & 20.77 & 6.08 & -3.31 \\
\hline South Africa & 0.84 & 0.91 & 0.99 & 5.58 & 5.51 & 5.56 & 0.91 & 1.72 & -0.10 & -0.94 \\
\hline Sudan & 1.48 & 1.92 & 2.00 & 10.71 & 9.61 & 9.71 & 7.88 & 8.54 & 0.26 & -0.96 \\
\hline Tanzania & 0.61 & 0.98 & 1.06 & 7.49 & 7.65 & 7.73 & 4.22 & 5.00 & -0.08 & -0.99 \\
\hline Uganda & 0.06 & 1.07 & 1.15 & 9.25 & 8.74 & 8.84 & 15.38 & 15.38 & 16.20 & -1.11 \\
\hline Zambia & -1.55 & -1.11 & -1.03 & 8.83 & 8.46 & 8.55 & 9.23 & 9.23 & 10.35 & -1.42 \\
\hline Zimbabwe & -0.45 & 0.08 & 0.16 & 9.93 & 7.24 & 7.33 & 15.35 & 15.35 & 16.32 & -1.22 \\
\hline
\end{tabular}

Notes: See Tables 2 and 3. The first six columns provide observed and synthetic measures of the mean and standard deviation of consumption growth by country. $\hat{\mu}_{i}$ and $\hat{\sigma}_{i}$ are the mean and standard deviation of observed consumption growth for each country $i$. $\widehat{\mu}_{i}^{*^{\prime}}$ is the estimate of the $i^{\text {th }}$ country's consumption growth rate if it were only to enjoy the local-direct benefits from peace, while $\widehat{\mu}_{i}^{*}$ includes both the local-direct and global benefits to consumption growth from peace. $\widehat{\sigma}_{i}^{*^{\prime}}$ is the estimate of the $i^{\text {th }}$ country's consumption growth volatility (i.e. standard deviation) if it were only to enjoy the local-direct benefits from peace, while $\widehat{\sigma}_{i}^{*}$ includes both the local-direct and global benefits to consumption volatility from peace. The welfare calculations are obtained using expressions (6) for the values $\rho=2.0$ and $\theta=.08$. Note that while all countries will benefit from reduced conflict due to the global effect of improved world consumption growth, I only report in Table 4 the welfare improvement for countries who have been directly involved in conflict. The average values of $\tau_{i}^{*}$ for countries that did not engage in conflict is 0.72 . The last two columns of Table 4 display the elasticity of $\tau_{i}^{*}$ with respect to $\rho$ and $\theta$ - the formulae are contained in footnote 25. 
Table 4 (Continued): Welfare Calculations

\begin{tabular}{|c|c|c|c|c|c|c|c|c|c|c|}
\hline & \multicolumn{3}{|c|}{ Growth } & \multicolumn{3}{|c|}{ Volatility } & \multicolumn{2}{|c|}{ Cost } & \multicolumn{2}{|c|}{ Elasticity } \\
\hline Country & $\hat{\mu}_{i}$ & $\hat{\mu}_{i}^{*^{\prime}}$ & $\hat{\mu}_{i}^{*}$ & $\hat{\sigma}_{i}$ & $\hat{\sigma}_{i}^{*^{\prime}}$ & $\hat{\sigma}_{i}^{*}$ & $\tau_{i}^{*^{\prime}}$ & $\tau_{i}^{*}$ & $\epsilon_{\tau_{i}^{*} \rho}$ & $\epsilon_{\tau_{i}^{*} \theta}$ \\
\hline \multicolumn{11}{|c|}{ Latin-America } \\
\hline Argentina & 0.61 & 1.39 & 1.47 & 5.51 & 4.98 & 5.04 & 9.93 & 10.76 & -0.10 & -0.96 \\
\hline Chile & 1.48 & 1.66 & 1.73 & 13.23 & 13.07 & 13.20 & 2.76 & 3.28 & 0.31 & -1.04 \\
\hline Dominican R. & 2.11 & 2.64 & 2.72 & 7.92 & 7.35 & 7.45 & 6.30 & 6.92 & -0.23 & -0.85 \\
\hline El Salvador & 0.36 & 0.78 & 0.86 & 5.10 & 4.63 & 4.68 & 5.65 & 6.53 & 0.02 & -0.99 \\
\hline Guatemala & 0.78 & 0.95 & 1.03 & 3.08 & 3.11 & 3.14 & 1.96 & 2.80 & -0.21 & -0.92 \\
\hline Honduras & 0.70 & 0.94 & 1.02 & 3.41 & 3.53 & 3.57 & 2.67 & 3.51 & -0.20 & -0.93 \\
\hline Nicaragua & -1.29 & -1.06 & -0.99 & 9.54 & 8.19 & 8.29 & 8.30 & 9.39 & 1.32 & -1.39 \\
\hline Panama & 1.66 & 1.77 & 1.84 & 6.95 & 6.97 & 7.05 & 1.10 & 1.79 & -0.32 & -0.87 \\
\hline Peru & 0.37 & 0.37 & 0.45 & 5.92 & 5.89 & 5.95 & 0.06 & 0.92 & 0.00 & -1.00 \\
\hline Uruguay & 0.58 & 0.69 & 0.77 & 5.92 & 5.94 & 6.00 & 1.25 & 2.08 & -0.09 & -0.97 \\
\hline \multicolumn{11}{|c|}{ E. Europe } \\
\hline Greece & 3.99 & 3.99 & 4.06 & 3.04 & 3.03 & 3.06 & 0.00 & 0.59 & -0.72 & -0.68 \\
\hline Yugoslavia & 4.08 & 4.08 & 4.15 & 10.53 & 10.23 & 10.34 & 0.56 & 1.02 & -0.12 & -0.74 \\
\hline \multicolumn{11}{|c|}{ W. Europe (Non - G7) } \\
\hline Cyprus & 5.84 & 6.61 & 6.69 & 7.59 & 6.07 & 6.15 & 6.82 & 7.26 & -0.69 & -0.62 \\
\hline Portugal & 4.32 & 4.65 & 4.73 & 5.71 & 5.74 & 5.80 & 2.55 & 3.08 & -0.74 & -0.68 \\
\hline Turkey & 2.44 & 2.51 & 2.59 & 4.27 & 4.06 & 4.10 & 0.83 & 1.50 & -0.38 & -0.78 \\
\hline \multicolumn{11}{|c|}{ Oceana } \\
\hline Australia & 1.93 & 2.00 & 2.08 & 1.84 & 1.83 & 1.85 & 0.69 & 1.42 & -0.43 & -0.81 \\
\hline \multicolumn{11}{|c|}{ S.E. Asia (Non - G7) } \\
\hline China & 2.69 & 3.44 & 3.52 & 5.57 & 5.25 & 5.30 & 7.18 & 7.82 & -0.51 & -0.78 \\
\hline India & 1.49 & 2.21 & 2.29 & 4.73 & 4.45 & 4.49 & 7.82 & 8.57 & -0.33 & -0.87 \\
\hline Indonesia & 3.03 & 3.46 & 3.54 & 3.99 & 4.06 & 4.10 & 3.72 & 4.35 & -0.62 & -0.74 \\
\hline Korea (ROK) & 5.40 & 5.80 & 5.87 & 4.07 & 4.25 & 4.29 & 2.62 & 3.12 & -0.91 & -0.62 \\
\hline Philippines & 1.09 & 1.65 & 1.73 & 2.72 & 2.82 & 2.85 & 6.05 & 6.85 & -0.32 & -0.89 \\
\hline Thailand & 3.58 & 3.97 & 4.05 & 3.82 & 3.60 & 3.64 & 3.34 & 3.94 & -0.64 & -0.71 \\
\hline \multicolumn{11}{|c|}{ Middle East } \\
\hline Bangladesh & 0.29 & 0.40 & 0.47 & 6.37 & 5.72 & 5.79 & 2.34 & 3.20 & 0.33 & -1.01 \\
\hline Iran & 0.83 & 2.50 & 2.58 & 9.83 & 7.65 & 7.76 & 25.50 & 26.24 & 0.08 & -1.02 \\
\hline Iraq & -0.31 & 1.86 & 1.94 & 17.45 & 15.14 & 15.29 & 64.65 & 65.27 & 1.96 & -1.74 \\
\hline Israel & 3.37 & 4.23 & 4.31 & 4.73 & 4.82 & 4.87 & 7.20 & 7.79 & -0.68 & -1.72 \\
\hline Jordan & 2.87 & 3.33 & 3.40 & 10.82 & 10.71 & 10.82 & 4.71 & 5.22 & -0.30 & -0.83 \\
\hline Pakistan & 2.09 & 2.92 & 3.00 & 6.32 & 5.75 & 5.80 & 8.94 & 9.62 & -0.37 & -0.83 \\
\hline Saudi Arabia & 5.53 & 5.87 & 5.94 & 9.73 & 9.49 & 9.58 & 2.86 & 3.27 & -0.66 & -0.65 \\
\hline Syria & 3.46 & 4.77 & 4.85 & 15.37 & 14.74 & 14.90 & 15.75 & 16.02 & -0.04 & -0.89 \\
\hline \multicolumn{11}{|c|}{ G7 } \\
\hline Canada & 2.38 & 2.45 & 2.52 & 2.74 & 2.56 & 2.59 & 0.74 & 1.44 & -0.43 & -0.78 \\
\hline France & 2.85 & 3.15 & 3.23 & 1.49 & 1.54 & 1.55 & 2.62 & 3.28 & -0.60 & -0.74 \\
\hline Italy & 3.92 & 3.99 & 4.07 & 2.26 & 2.21 & 2.23 & 0.57 & 1.16 & -0.70 & -0.68 \\
\hline U.K. & 2.16 & 2.42 & 2.49 & 2.56 & 2.40 & 2.43 & 2.50 & 3.21 & -0.45 & -0.80 \\
\hline U.S.A. & 2.04 & 2.30 & 2.37 & 1.84 & 1.88 & 1.90 & 2.44 & 3.16 & -0.47 & -0.80 \\
\hline
\end{tabular}


welfare calculations. To demonstrate this, columns 9 and 10 of Table 4 present the point elasticity measure of $\tau_{i}$ with respect to $\rho$ and $\theta, \epsilon_{\tau_{i} \theta}$ and $\epsilon_{\tau_{i} \rho}$, respectively. ${ }^{25}$ These elasticity measures answer the following simple question: If the value of $\rho(\theta)$ changes by $\mathrm{x}$ percentage points, by how many percentage points does $\tau_{i}$ change? Namely, by $\% \Delta \tau_{i}=x \cdot \epsilon_{\tau_{i} \rho}$.

Table 4 affirms that the world could benefit greatly from eliminating conflict. ${ }^{26}$ Estimates of the economic cost of conflict for each country are given in columns 7 and 8 . The estimates differ depending on whether or not the global benefit to a country if all conflict is removed. The table is arranged by region. This table has two key findings. First, most countries, many of whom are quite poor, would be willing to permanently pay a substantial amount to live a peaceful world. For example, in Africa, the countries who would gain the most from peace would be Angola and the Congo. I find that a citizen of the Angola would permanently give up to 40.5 percent of his current level of consumption in order to live in a peaceful world (38.2 percent if only local-direct effects are allowed), while a citizen of the Congo would give up 33.2 (32.3) percent. Argentina, Cyprus, India and Iraq are countries that would pay the most in their respective regions to live in a more peaceful world. ${ }^{27}$ Argentina would permanently give up about 11 percent of current consumption to live in peace, Cyprus and India 7 to 8 percent, while Iraq would willingly sacrifice around 65 percent of current consumption.

Second, using a relatively low value of $\rho$ and a high value of $\theta$ suggests that, on average, I am computing a lower bound estimate of the benefits of peace. Returning to the example of

$$
\begin{aligned}
& { }^{25} \text { The formulae for these measures are: } \\
& \epsilon_{\tau_{i} \rho}=\left[\frac{\rho /(1-\rho)}{\tau_{i} /\left(1+\tau_{i}\right)}\right] \cdot\left[\log \left(1+\tau_{i}\right)+\left(\frac{\Phi_{i}\left(\log \left(1+\mu_{i}\right)+(1-2 \rho) \sigma_{i}^{2} / 2\right)}{1-\Phi_{i}}\right)-\left(\frac{\Phi_{i}^{*}\left(\log \left(1+\mu_{i}^{*}\right)+(1-2 \rho) \sigma_{i}^{2 *} / 2\right)}{1-\Phi_{i}^{*}}\right)\right] \\
& \epsilon_{\tau_{i} \theta}=\left[\frac{\theta /(1+\theta)}{(1-\rho) \tau_{i} /\left(1+\tau_{i}\right)}\right]\left[\left(\frac{\Phi_{i}}{1-\Phi_{i}}\right)-\left(\frac{\Phi_{i}^{*}}{1-\Phi_{i}^{*}}\right)\right]
\end{aligned}
$$

\footnotetext{
${ }^{26}$ While all countries will benefit from reduced conflict due to the global effect of improved world consumption growth, only the welfare improvement for countries who have been directly involved in conflict are reported in Table 4. The average value of $\tau_{i}$ for countries that did not engage in conflict is 0.72 . One can consider this to be the measure of a global "peace dividend."

${ }^{27}$ The calculations for the G7, Oceana and Eastern Europe are quite a bit lower and so are not discussed in detail. However, it is worth noting that the benefit from eliminating business cycles using Lucas' original calculation-where shocks to the log-level of consumption are i.i.d. around a deterministic trend - is 0.07 percent for the United States. If instead I use the same methodology and perform a Lucas-type calculation of the benefit from eliminating the innovations to the consumption growth rate, this increases to 0.33 percent. The United States' global benefit from eliminating conflict (3.2 percent) clearly outweighs both of these other calculations.
} 
Angola, the elasticiy of $\tau_{i}$ with respect to $\rho\left(\epsilon_{\tau_{i} \rho}\right)$ is 3.82 which implies that doubling $\rho$ from 2 to 4 would increase $\tau_{i}$ by $382 \%$ - namely, to 155 percent of current consumption. Similarly, the elasticiy of $\tau_{i}$ with respect to $\theta\left(\epsilon_{\tau_{i} \theta}\right)$ is -2.36 implies that decreasing $\theta$ from .08 to .04 would increase $\tau_{i}$ by $236 \%$ - namely to 95 percent of current consumption. From Table 4, however, one can see that $\epsilon_{\tau_{i} \theta}$ are all negative, suggesting that choosing a high discount factor of $\theta=.08$ is biasing down the estimates of the consumption welfare cost of conflict. In contrast, the effect of a rise in the coefficient of relative risk aversion, $\rho$, has ambiguous effects on the change in $\tau_{i}$. Indeed for many countries, such as those in the G7, the reported values for $\epsilon_{\tau_{i} \rho}$ are negative. For the U.S., in fact, doubling $\rho$ from 2 to 4 would lower $\tau_{i}^{*}$ by about one-half, so that the consumption welfare cost of conflict would be about 1.5 percent of current consumption. However, as demonstrated in Table 5 below, on average the value for $\epsilon_{\tau_{i} \rho}$ is positive, so that the selection of a relatively low value of $\rho=2$ is not systematically lowering the value of $\tau_{i}^{*}$ for the average country.

The top panel of Table 5 summarizes the findings reported in Table 4. On average, a world consumer who lives in a country that has experienced conflict over the time period considered (top row), would willingly give up approximately 9 percent of his annual level of consumption as a one time payment in order to live in a world of perpetual peace. Taking the first panel of Table 5, row one indicates that the average estimated annual per-capita consumption growth on the synthetic, conflict-free consumption path $\left(\widehat{\mu}^{*}\right)$ is 0.57 percentage points higher than the average observed consumption growth $(\widehat{\mu})$. Similarly, the average of the standard deviation of 'peaceful' consumption growth, $\widehat{\sigma}^{*}=7.21$, is less than the volatility of observed consumption growth, $\widehat{\sigma}=7.66$. Also, the average elasticity of the welfare measure $\tau_{i}^{*}$ with respect to $\rho$ and $\theta$ are positive and negative, respectively, suggesting that higher values of $\rho$ and lower values of $\theta$ will make the costs of war higher. Moreover, the average value of $\epsilon_{\tau_{i} \theta}$ is approximately -1 , while that for $\epsilon_{\tau_{i} \rho}$ is closer to zero, with the latter having a standard deviation that is over two times larger than the former. ${ }^{28}$

In the remaining panels of Table 5 I experiment with broader specifications for how conflict affects a country's expected consumption path. To wit, I allow for region specific variation in the $\widehat{\alpha}$ 's and $\widehat{\delta}$ 's. I also attempt to control for possible reverse causality of weak consumption growth leading

\footnotetext{
${ }^{28} \mathrm{~A}$ simple test reveals that the average value for $\epsilon_{\tau_{i} \theta}\left(\epsilon_{\tau_{i} \rho}\right)$ is (is not) significantly different from zero in a two-tailed test at or below the .10 level.
} 
Table 5: Robustness of Welfare Calculations

\begin{tabular}{|l|r|r|r|r|r|r|r|r|r|r|}
\hline \multicolumn{1}{|c|}{ Uncensored without Regional Parameter Variation } \\
\hline & \multicolumn{3}{|c|}{ Growth } & \multicolumn{3}{|c|}{ Volatility } & \multicolumn{2}{|c|}{ Cost } & \multicolumn{3}{|c|}{ Elasticity } \\
\hline Country & $\hat{\mu}_{i}$ & $\hat{\mu}_{i}^{*^{\prime}}$ & $\hat{\mu}_{i}^{*}$ & $\hat{\sigma}_{i}$ & $\hat{\sigma}_{i}^{*^{\prime}}$ & $\hat{\sigma}_{i}^{*}$ & $\tau_{i}^{*^{\prime}}$ & $\tau_{i}^{*}$ & $\epsilon_{\tau_{i}^{*} \rho}$ & $\epsilon_{\tau_{i}^{*} \theta}$ \\
\hline average & 1.34 & 1.83 & 1.91 & 7.66 & 7.13 & 7.21 & 8.61 & 9.35 & 0.21 & -1.04 \\
std & 1.91 & 1.93 & 1.93 & 4.26 & 3.85 & 3.89 & 11.02 & 11.09 & 1.15 & 0.44 \\
median & 1.15 & 1.73 & 1.81 & 6.51 & 6.20 & 6.28 & 5.52 & 6.35 & -0.10 & -0.94 \\
\hline
\end{tabular}

\begin{tabular}{|l|r|r|r|r|r|r|r|r|r|r|}
\hline \multicolumn{10}{|c|}{ Censored without Regional Parameter Variation } \\
\hline & \multicolumn{3}{|c|}{ Growth } & \multicolumn{3}{|c|}{ Volatility } & \multicolumn{2}{|c|}{ Cost } & \multicolumn{3}{|c|}{ Elasticity } \\
\hline Country & $\hat{\mu}_{i}$ & $\hat{\mu}_{i}^{*^{\prime}}$ & $\hat{\mu}_{i}^{*}$ & $\hat{\sigma}_{i}$ & $\hat{\sigma}_{i}^{*^{\prime}}$ & $\hat{\sigma}_{i}^{*}$ & $\tau_{i}^{*^{\prime}}$ & $\tau_{i}^{*}$ & $\epsilon_{\tau_{i}^{*} \rho}$ & $\epsilon_{\tau_{i}^{*} \theta}$ \\
\hline average & 1.36 & 1.85 & 1.88 & 7.92 & 7.41 & 7.39 & 8.89 & 9.40 & 0.30 & -1.05 \\
std & 1.97 & 1.98 & 1.98 & 4.16 & 3.83 & 3.81 & 12.61 & 12.80 & 1.20 & 0.45 \\
median & 1.15 & 1.67 & 1.70 & 6.84 & 6.49 & 6.51 & 5.56 & 5.73 & 0.02 & -0.95 \\
\hline
\end{tabular}

\begin{tabular}{|l|r|r|r|r|r|r|r|r|r|r|}
\hline \multicolumn{10}{|c|}{ Uncensored with Regional Parameter Variation } \\
\hline & \multicolumn{3}{|c|}{ Growth } & \multicolumn{3}{|c|}{ Volatility } & \multicolumn{2}{|c|}{ Cost } & \multicolumn{3}{|c|}{ Elasticity } \\
\hline Country & $\hat{\mu}_{i}$ & $\hat{\mu}_{i}^{*^{\prime}}$ & $\hat{\mu}_{i}^{*}$ & $\hat{\sigma}_{i}$ & $\hat{\sigma}_{i}^{*^{\prime}}$ & $\hat{\sigma}_{i}^{*}$ & $\tau_{i}^{*^{\prime}}$ & $\tau_{i}^{*}$ & $\epsilon_{\tau_{i}^{*} \rho}$ & $\epsilon_{\tau_{i}^{*} \theta}$ \\
\hline average & 0.98 & 1.54 & & 8.36 & 7.26 & & 12.53 & & 0.62 & -1.10 \\
std & 1.82 & 1.77 & & 4.17 & 3.71 & & 18.55 & & 1.37 & 0.47 \\
median & 0.78 & 1.11 & & 7.49 & 6.62 & & 6.87 & & 0.35 & -0.98 \\
\hline
\end{tabular}

\begin{tabular}{|l|r|r|r|r|r|r|r|r|r|r|}
\hline \multicolumn{10}{|c|}{ Censored with Regional Parameter Variation } \\
\hline & \multicolumn{3}{|c|}{ Growth } & \multicolumn{3}{|c|}{ Volatility } & \multicolumn{2}{|c|}{ Cost } & \multicolumn{3}{|c|}{ Elasticity } \\
\hline Country & $\hat{\mu}_{i}$ & $\hat{\mu}_{i}^{*^{\prime}}$ & $\hat{\mu}_{i}^{*}$ & $\hat{\sigma}_{i}$ & $\hat{\sigma}_{i}^{*^{\prime}}$ & $\hat{\sigma}_{i}^{*}$ & $\tau_{i}^{*^{\prime}}$ & $\tau_{i}^{*}$ & $\epsilon_{\tau_{i}^{*} \rho}$ & $\epsilon_{\tau_{i}^{*} \theta}$ \\
\hline average & 0.88 & 1.59 & & 8.17 & 7.49 & & 14.16 & & 0.38 & -1.10 \\
std & 1.59 & 1.43 & & 4.29 & 4.02 & & 23.08 & & 2.15 & 0.46 \\
median & 0.80 & 1.55 & & 6.84 & 6.73 & & 5.90 & & -0.10 & -0.98 \\
\hline
\end{tabular}

Notes: See Table 4. The top panel provides cross-country summary statistics for the data in Table 4. The rows report the mean, standard deviation and median of the cross country statistics for each column. The second panel repeats this exercise when all conflicts are censored as follows: if the conflict is preceded by a year when the growth of per-capita consumption is more than one standard deviation below the country's mean per-capita consumption growth, the conflict is not counted as having occurred. Though not shown, this will change the estimated parameters in Tables 2 and 3. The third panel returns to the non-censored definition of conflict, though the estimated parameters in equation (8) were obtained by estimating the equation separately over the following regional sub-samples: Africa, Latin America, South East Asia (non-G7), Latin America, Oceana, Eastern Europe, Western Europe (non-G7) and G7. The fourth panel allows for both the censored definition of conflict and region-by-region parameter variation. Only local-direct effects of conflict $\hat{\mu}^{*^{\prime}}$ and $\hat{\sigma}^{*^{\prime}}$ are reported when estimating over the regional sub-samples. 
to conflict, such as the "diversionary wars" of the type suggested by Hess and Orphanides (1995). Hess and Orphanides (1995) develop a diversionary theory of external conflict wherein elected leaders with innate but unknown conflict handling skills may initiate conflict during economic downturns in order to reveal these skills and help their chances at re-election. ${ }^{29}$ Accordingly, I explore censoring the data such that if a conflict is immediately preceded by a year when percapita consumption growth was more than one standard deviation below the country's average per-capita consumption growth, the conflict is not counted as having occurred.

The results presented in the final three panels of Table 5 are broadly in line with the base specification. In general, these modifications slightly increase the average estimated cost of conflict. Censoring the war data without allowing for regional variation (panel 2) only slightly increases the average global and local-direct welfare gains from peace but decreases the median gain. Censoring also significantly increases the average local-direct gain from peace but again decreases the median when regional variation is allowed (panels 3 and 4). Allowing for region by region estimation of the effect of conflict on growth increases the average and median gain from peace irrespective of censoring. The average elasticity of $\tau_{i}$ with respect to $\rho$ remains positive across all panels, while the elasticity of $\tau_{i}$ with respect to $\theta$ is essentially unaffected at -1.0 .

To further understand the potential benefits to a country from living in a peaceful world, Table 6 reports empirical results for the factors which influence these benefits. In particular, I am interested in the regional, economic and governmental influences that indicate whether a country is more likely to gain from a peaceful world. The dependent variable in each regression is a country's willingness to pay in order to move to a more peaceful world. All countries for which there are data are used in these empirical estimates, since all countries may enjoy the global benefits from reduced conflict. Hence, there is data for 147 countries rather than just those listed in Table 4 . The general specification is:

$$
\tau_{i}^{*}=\text { Constant }+R_{i}+\theta_{1} \cdot \text { Economics }_{i}+\theta_{2} \cdot \text { DEMO }_{i}+\theta_{3} \cdot\left(\text { Economics }_{i} \times D E M O_{i}\right)+v_{i},
$$

\footnotetext{
${ }^{29}$ As Meade (1940) states: "Poverty, and in particular the fall from comfort to poverty in a period of national economic collapse, breeds a state of mind in which military adventures appear more attractive than would otherwise be the case." (p. 15)
} 
$\tau_{i}^{*}=$ Constant $+R_{i}+\theta_{1} \cdot$ Economics $_{i}+\theta_{2} \cdot D E M O_{i}+\theta_{3} \cdot\left(\right.$ Economics $\left._{i} \times D E M O_{i}\right)+v_{i}$

Table 6: Factors Influencing A Country's Potential Gain from Peace

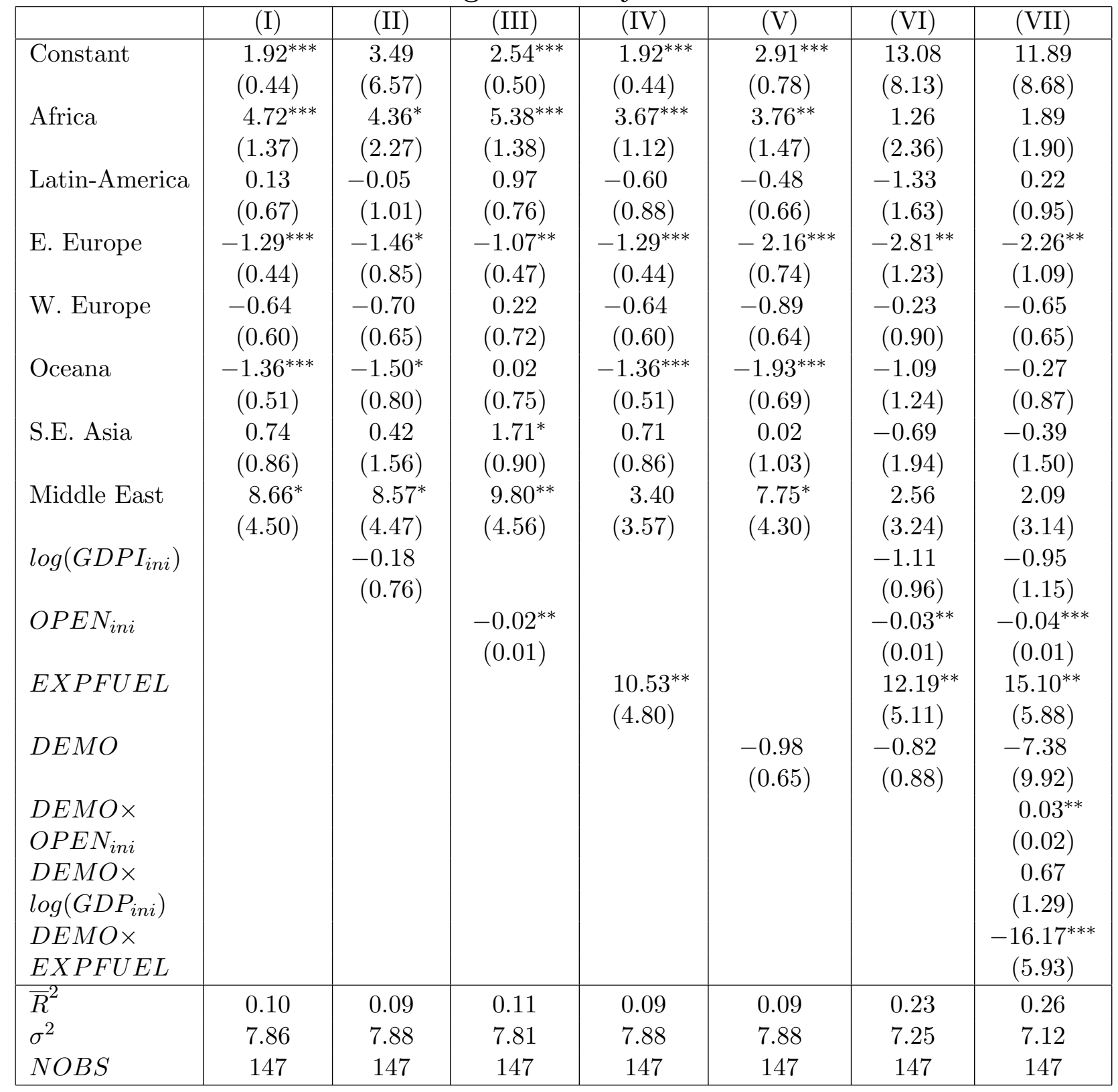

Notes: Regressions include all 147 countries for which data are available as all countries may enjoy the global benefits from reduced conflict. The dependent variable in each regression is $\tau_{i}^{*}$ compute for $\rho=2.0 \theta=.08$. $R_{i}$ are the regional dummy variables (G7 countries omitted). $D E M O_{i}=1$ indicates that the government was deemed democratic at the beginning of the sample. The economic variables I consider are each country's initial log-level of real GDP per-capita, whether a country's exports are more than fifty percent related to fuel $(E X P F U E L=1)$ and the initial openness of each country's economy $(O P E N)$, as measured by initial exports plus imports, divided by GDP-see the Data Appendix. Table 6 indicates that Eastern European countries would be willing to give up less consumption growth than the G7 to live in a state of peace. However, if Eastern Europe is dropped from the sample (not shown) the regression is virtually unchanged. 
where $R_{i}$ represents the estimated regional effects. The governance variable in the regression is $D E M O_{i}$ which indicates whether the government was deemed to be democratic or not at the beginning of the sample-See Gurr and Harff (1997). The economic variables considered are the country's initial log-level of real GDP per-capita, whether the country's exports are more than fifty percent related to fuel (EXPFUEL) and the initial openness of each country's economy $(O P E N)$, as measured by initial exports plus imports, divided by GDP-see the Data Appendix.

In column (I) of Table 6, I present the empirical results when just the regional effects are estimated. Notice that in order to avoid collinearity, I include a constant though G7 is removed as an explanatory variable. Interestingly, the regional variation suggests that, relative to the G7 countries, Africa and the Middle East have significantly more to gain from a more peaceful world, while Eastern Europe and Oceana have less to gain. ${ }^{30}$ In columns (II) through (V), I present evidence on the additional impact of economic factors on the welfare costs of conflict. The regression results indicate that the primary economic factor is a country's openness and whether the country is a fuel exporter - columns (III) and (IV). As for the former finding, an increase in a country's trade sector tends to lower their expected gain from peace. In other words, closed economies have more to gain from peace than do open economies. Of course, given the strong empirical evidence on the liberal peace espoused by Bruce Russett (2002) and others, this is likely due to the fact that more open economies are less likely to be engaging in conflict anyway. As for the latter finding, many of the worlds major oil producing nations are concentrated in high conflict areas and are more likely to be involved in a higher rate of conflict - hence peace will bring them greater benefits. Somewhat ironically, abundant petroleum resources may simply be a mixed blessing for a country. Another interesting finding is that a country's initial level of real GDP does not affect the benefits from peace - column (II). The empirical results presented in column (V) suggest that a country's democratic governance does not directly affect its benefits from peace. Column (VI) of Table 6, when all these variables are included simultaneously, indicates that the pattern of regional variation as well as the role of openness and fuel exports, are unchanged.

\footnotetext{
${ }^{30}$ Table 6 indicates that Eastern European countries would be willing to give up less consumption growth than the G7 to live in a state of peace. As mentioned before, however, there may be some anomalies in the coding of conflicts for Eastern Europe - e.g., the USSR in Afghanistan. However, if Eastern Europe is dropped from the sample (not shown) the regression is virtually unchanged.
} 
To explore whether a country's democratic governance affects its benefits from peace indirectly through its economic conditions, in column (VII) of Table 6 I present estimates where I include the interaction terms between the economic variables and democracy. A few interesting finding emerge from this regression. First, Democratic governments that are more open to trade have more to gain from peace. Second, non-Democratic fuel exporters also have the most to gain from peace. Again, these countries are more likely to gain from peace because these types of countries are more likely to be currently engaged in a higher frequency of welfare reducing conflict. As such, they will have the most to gain from peace. The other estimated coefficients are largely unaffected by the inclusion of these additional variables.

\section{Conclusion}

Following Lucas (1987), this paper estimates the potential economic gain from peace as the certainty equivalent of how much individuals would be willing to give up of their current consumption up in order to live in a peaceful world. Using panel data for 147 countries, I calculate a synthetic path of consumption that removes the effects of war on the mean and volatility of consumption growth. From these estimates, the cost of conflict are calculated. The main finding is that a lower bound estimate of the average benefit from eliminating war is about 8 percent of per capita annual consumption. In addition, though many of the poorest countries stand to benefit greatly from peace, the benefits to developed economies can often be substantial (see Figure 1). The results are robust to regional effects and possible reverse causality of the type considered by Hess and Orphanides (1995). Further, both data limitations and the nature of this technique suggest that the calculation represents a lower bound estimate of the possible gain from eliminating conflict.

In an attempt to assign an actual dollar value to this lower bound estimate of the cost of war, at an admitted loss of generality, multiply each country's calculated cost of conflict $\left(\tau_{i}\right)$ by their actual per-capita and total consumption in 1985 international dollars. By this measure, the average (world) cost of conflict is $\$ 72$ per person ( $\$ 142$ for countries appearing in Table 4 ). The countries whose citizens would be willing to pay the most to avoid conflict are Iraq $(\$ 1,220)$, Iran 
Figure 1: Cost of Conflict $\left(\tau_{i}^{*}\right)$ by Country

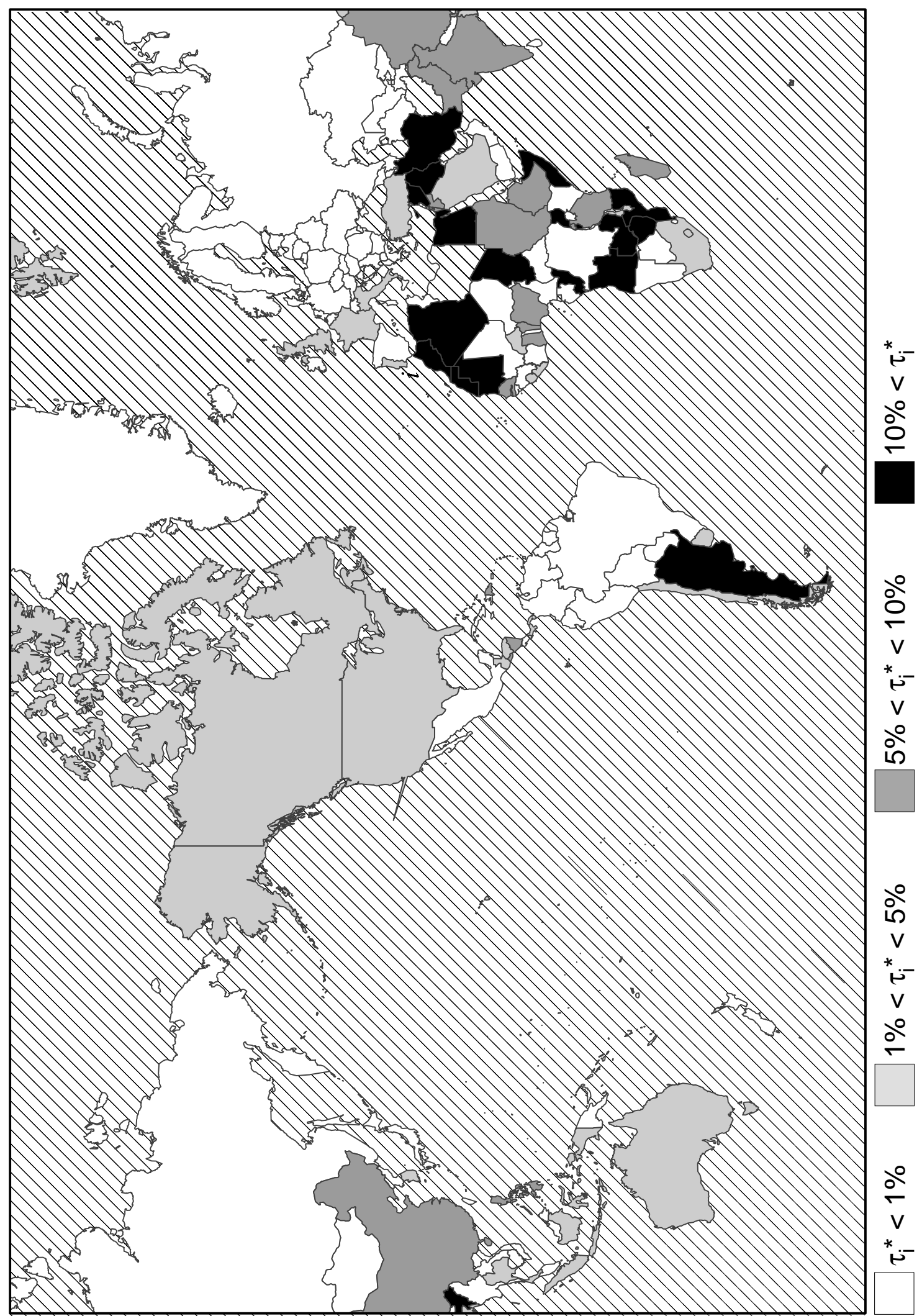

Notes: Welfare calculations are obtained using expression (6). All countries for which data are available are pictured in Figure (1) as all countries may enjoy the global benefits of reduced conflict. 
(\$719), Qatar (\$489), Algeria (\$467), and Syria (\$457). The United States ranks 8th highest at \$353. Recall that these are not one-time payments, but a permanent per-capital payment, so that the simple present discounted value is twenty-one times higher for a risk free rate of 5 percent. Similarly, the total world cost of conflict in 1985 dollars and for the 1985 population is $\$ 399.12$ billion, and this permanent payment would grow at the rate of population growth. In 1985 dollars and population, the United States, China, India, Iran, and Iraq as countries face the highest costs of conflict- $\$ 84.5, \$ 66.1, \$ 39.3, \$ 33.4$, and $\$ 18.7$ billion, respectively. The magnitude of the potential consumption welfare and dollar gains from eliminating conflict should make economists, political scientists, and policy-makers continue to investigate and advocate for domestic and international institutions to realize such gains. 


\section{References}

Alesina, Alberto and Spolaore, Enrico. "Conflict, Defense Spending and the Size of Countries," mimeo, (June 2000).

Arellano, Manual and Bond, Stephen. "Some Tests of Specification for Panel Data: Monte Carlo Evidence and an Application to Employment Equations," Review of Economic Studies 58, (April 1991): pp. 277-297.

Bleaney, Michael, Gemmell, Norman, and Kneller, Richard.. "Testing the Endogenous Growth Model: Public Expenditure, Taxation, and Growth Over the Long Run," Canadian Journal of Economics 34, (February 2001): pp. 36-57.

Blomberg, S. Brock, Hess, Gregory, and Thacker, Sidharth. "Is There Evidence of a PovertyConflict Trap?" mimeo, (2001).

Blomberg, S. Brock, and Hess, Gregory. "The Temporal Links Between Conflict and Economic Activity," Journal of Conflict Resolution 46, (February 2002): pp. 74-90.

Braun, R. Anton and McGrattan, Ellen. "The Macroeconomics of War and Peace," In NBER Macroeconomics Annual. Cambridge, MA: MIT Press, 1993.

Brecher, Michael, Wilkenfeld, Jonathan, and Moser, Sheila. "Crises in the Twentieth Century," In Handbook of International Crises, Volume I, Oxford, UK: Pergamon Books, 1988.

Brecher, Michael, and Wilkenfeld, Jonathan. A Study of Crisis. Ann Arbor, MI: University of Michigan Press, 1997.

Collier, Paul and Sambanis, Nicholas. "Understanding Civil War: A New Agenda", Journal of Conflict Resolution 46, (February 2002): pp. 3-12.

Crucini, Mario and Hess, Gregory D. "International and Intranational Risk Sharing," In Intranational Macroeconomics, edited by Gregory D. Hess and Eric Van Wincoop, Cambridge, UK: Cambridge University Press, 2000, pp. 37-59.

Garfinkel, Michelle R., and Skaperdas, Stergios. "Introduction: Conflict and Appropriation as Economic Activities." In The Political Economy of Conflict and Appropriation, edited by Michelle R. Garfinkel and Stergios Skaperdas. Cambridge, UK: Cambridge University Press, 1996.

Griffith, Samuel. Sun Tzu: The Art of War. Oxford, UK: Oxford University Press, 1963.

Hess, Gregory D. and Orphanides, Athanasios. "War Politics: An Economic, Rational Voter Framework." The American Economic Review 85, (September 1995): pp. 828-46.

Hess, Gregory D. and Orphanides, Athanasios. "Economic Conditions, Elections, and the Magnitude of Foreign Conflicts." The Journal of Public Economics 80, (April 2001): pp. 121-40.

Hess, Gregory D. and Orphanides, Athanasios. "War and Democracy." The Journal of Political 
Economy 109, (August 2001): pp. 776-810.

Howard, Michael. The Causes of War. Cambridge, MA: Harvard University Press, 1983.

Howard, Michael. The Invention of Peace: Reflections on War and International Order. New Haven, CT: Yale University Press, 2000.

Kaysen, Karl. "Is War Obsolete?" International Security 14, (Spring 1990): pp. 42-64.

Keegan, John. A History of Warfare. New York, NY: Vintage Books: Random House, Inc., 1993.

Keynes, John Maynard. The Economic Consequences of the Peace. London, UK: Macmillan and Co., 1919.

Lau, Morten I., Panu Poutvaara, and Andreas Wagener. "The Dynamic Cost of the Draft" CESifo Working Paper 774, (September 2002).

Lucas, Robert E., Jr. Models of Business Cycles. Oxford, UK: New York, NY, USA: Basil Blackwell, 1987.

McGrattan, Ellen and Ohanian, Lee. "The Macroeconomic Effects of Big Fiscal Shocks: The Case of World War II," Federal Reserve Bank of Minneapolis Working Paper Number 599 (December 1999).

Meade, James E. The Economic Basis of a Durable Peace. New York, NY: Oxford University Press, 1940.

Mueller, John. Retreat From Doomsday: The Obsolescence of Major War. New York, NY: Basic Books, Inc., 1989.

Nelson, Charles R. "A Reappraisal of Recent Tests of the Permanent Income Hypothesis," The Journal of Political Economy 95, (June 1987): pp. 641-46.

Newey, Whitney K. and West, Kenneth D. "A Simple, Positive Semi-definite, Heteroskedasticity and Autocorrelation Consistent Covariance Matrix," Econometrica 55, (May 1987): pp. 703-08.

Nordhaus, William. "The Economic Consequences of a War with Iraq," NBER Working Paper 9361, (December 2002).

Obstfeld, M. and Rogoff, Kenneth. Foundations of International Macroeconomics. Cambridge, MA: MIT Press, 1996.

Pigou, A. C. The Political Economy of War. London, UK: MacMillan and Co., 1940.

Quah, Danny. "Empirics for growth and distribution: Stratification, polarization, and convergence clubs," Journal of Economic Growth, (March 1997): 27-59.

Ramey, Valerie and Shapiro, Matthew. "Costly Capital Reallocation and the Effects of Government Spending," Carnegie Rochester Conference Series on Public Policy, (June 1998): pp. 145-94. 
Robbins, Lionel. The Economic Causes of War. London, UK: Jonathan Cape, 1942.

Russett, Bruce. "Violence and Disease: Trade as Suppressor of Conflict When Suppressors Matter," in Edward Mansfield and Brian Pollins, eds., Economic Interdependence and International Conflict: New Perspectives on an Enduring Debate Ann Arbor, MI: University of Michigan Press, forthcoming 2002 .

Sala i Martin, Xavier. "I Just Ran Two Million Regressions," The American Economics Review, (May 1997): pp. 178-83.

Small, Melvin, and Singer, J. David. Resort to Arms: International and Civil Wars, 1816-1980. Beverly Hills, CA: Sage Publications, 1982.

Summers, Robert and Heston, Alan. "The Penn World Tables (Mark 5): An Expanded Set of International Comparisons," The Quarterly Journal of Economics 106, (May 1991): pp. 327-68.

van Wincoop, Eric. "Welfare Gains from International Risk Sharing," The Journal of Monetary Economics 34, (October 1994): pp. 175-200.

Wright, Quincy. A Study of War. Chicago, IL: The University of Chicago Press, 1965. 


\section{Data Appendix}

\section{Omitted Countries and Countries Without Coded Conflict}

The following countries do not have a coded conflict: Austria, Bahamas, Bahrain, Barbados, Belgium, Belize, Bolivia, Botswana, Brazil, Bulgaria, Burkina Faso, Cameroon, Cape Verde Islands, Central African Republic, Comoros, Costa Rica, Czechoslovakia, Denmark, Djibouti, Ecuador, Fiji, Finland, Gabon, Gambia, East Germany, West Germany, Grenada, Guinea, Guinea-Bissau, Guyana, Haiti, Hong Kong, Hungary, Iceland, Ireland, Ivory Coast, Jamaica, Japan, Kenya, Kuwait, Laos, Luxembourg, Malawi, Malaysia, Mali, Malta, Mauritius, Mexico, Mongolia, Myanmar, Namibia, Nepal, Netherlands, New Zealand, Niger, Norway, Oman, Papua New Guinea, Paraguay, Poland, Puerto Rico, Qatar, Reunion, Seychelles, Singapore, Solomon Islands, Spain, St. Kitts \& Nevis, Suriname, Swaziland, Sweden, Switzerland, Taiwan, Togo, Trinidad \& Tobago, Tunisia, U.S.S.R., United Arab Emirates, Vanuatu, Venezuela, Western Samoa and Zaire.

The following countries are not considered for lack of data: Bhutan, Dominica, St. Lucia, St. Vincent \& the Grenadines and Tonga.

Economic Data

- Penn World Tables (Summers \& Heston)

- $\Delta \log \left(c_{i t}\right): \log$ difference of real GDP per capita in constant dollars using chain index (1985 international prices in PWT5) times consumption share of GDP (1985 international prices).

- GDP $P_{i n i}$ : initial level of real GDP per capita in constant dollars using chain index (1985 international prices in PWT5).

- OPEN $N_{i n i}$ : initial openness measured as the ratio of exports plus imports to GDP.

External Conflicts

- International Crisis Behavior Project: Actor Level Data Set: Brecher, Wilkenfeld and Moser (1997).

- EXTS: Full scale war (SEVVIO =4).

- Home $(\mathrm{H})$ : crisis took place on the crisis actor's home territory (CRACTLOC $=1$ ).

- Away (A): crisis did not take place on the crisis actor's home territory (CRACTLOC $\neq$ 1).

- Peace Science Society International: Correlates of War Inter-State War Data, 1816-1997 Correlates of War Extra-State War Data, 1816-1997.

- EXTB: Military conflicts between states (inter-state wars) or between state and nonstate actor (extra-state wars). 
- If a conflict satisfies both EXTB and EXTS, then it is viewed as big (EXTB). Distinguishing feature between the two is that EXTB is coded for more than 1,000 annual deaths.

Internal Conflict

- State Failure Task Force: Internal Wars and Failures of Governance, 1954-1996 Data Set, Gurr and Harff (1997).

- GENOCIDE: Genocide/Politicides with more than 1,000 annual casualties.

- ETHNIC: Ethnic wars with more than 1,000 annual deaths.

- REGIME: Abrupt or disruptive regime changes with significant armed violence.

- REVOLT: Revolutionary Wars with more than 1,000 annual deaths.

Global Development Network Growth Database: Social Indicators and Fixed Factors, Easterly and Sewadeh

- World Bank Group: Global Development Network Growth Database

- EXPFUEL: Major exporter of fuel/oil (greater than 50\% of total exports of goods and services).

- ETHFRAC: Ethnic fractionalization.

- DEMO: Democracy from Gurr and Harff (1997). Equal to 1 if a democracy and zero otherwise. 


\section{Supplemental Appendix}

Im, Pesaran and Shin (1995), hereafter IPS, provide a test for unit roots in heterogenous panel data sets that allows the alternative hypothesis to have heterogeneity of the autoregressive term $(\rho)$, in addition to heterogeneity in the intercept and trend coefficients as well as the serial correlation of the error term in the maintained hypothesis. They demonstrate the beneficial power and size properties of their test. Below, I demonstrate that conducting the empirical work in growth rates rather than in levels is suggested by the results from the IPS unit root tests.

The top row of Table A.1 presents the results for the standard IPS unit root test with trend on the log-level of per-capita consumption. The equation estimated, country by country, is:

$$
\Delta \log \left(c_{i t}\right)=\alpha_{i}+\left(\rho_{i}-1\right) \cdot \log \left(c_{i t-1}\right)+\sum_{j=1}^{p_{i}} \phi_{j} \cdot \Delta \log \left(c_{i t-j}\right)+\theta_{i} \cdot t+e_{i t}
$$

where $c_{i t}$ is per-capita consumption in country $i$ at time $t$. The null hypothesis is that $\rho_{i}=1$ against the alternative that $\rho_{i}<1$. The t-statistic that $\rho=1$ for the $i^{t h}$ country, denoted $t_{i}(\rho=1)$, is then averaged across all $\mathrm{N}$ countries, $\bar{t}=N^{-1} \sum_{i=1}^{N} t_{i}(\rho=1)$, and compared to the critical values in IPS. The estimated value of $\hat{\bar{t}}=-1.78$ reported in the top row of Table A.1 is considerably smaller in absolute value than the 10 percent critical value of approximately -2.28 . Hence, I cannot reject the null hypothesis of a unit root at even the .1 critical level. ${ }^{A .1}$

I also consider two standard modifications to the IPS unit root test in order to gauge the robustness of the findings. First, subtract each country's first observation from the entire series and avoid estimating the fixed effects. This has been shown to lessen the bias problem pointed out in Nickel (1981) in OLS estimates of the autoregressive term in a panel data AR model with fixed effects. Second, dependence of shocks across countries can be controlled for, albeit imperfectly, by also subtracting out cross country time averages from each country's observation. ${ }^{A .2}$ Combinations of these two modifications are presented in the remaining rows of Table A.1. Importantly, however, these changes in specification do not affect the result that the evidence supports the view that I should model the effect of shocks to consumption in growth rates rather than in levels.

IPS do make the caveat, however, that given the heterogeneity of the panel data, I cannot infer that a unit root can be rejected for all countries. To better gauge the inability to reject a unit root, note that the univariate Dickey-Fuller t-statistic for rejecting a unit root at the .10 level is -3.18 for the case of a constant and trend with 50 observations. However, in all cases, less than 10 percent of the countries have individual t-statistics on $\rho=1, t_{i}(\rho=1)$, that are less than -3.18 . Again, this provides further support for the empirical specification that shocks to consumption are best modelled in growth rates rather than in log-levels.

\footnotetext{
${ }^{A .1}$ The reported estimates are obtained two lags of consumption growth as explanatory variables. IPS recommend a generous lag length to insure that their test perform well in the presence of serially correlated errors. Increasing the lag length to four, which is quite generous given that there are at most 34 observations per country, actually lowers the estimate of does $\bar{t}$, which strengthens the results.

${ }^{A .2} \mathrm{~A}$ simple solution for how to control for more general types of dependence has remained illusive. For instance, adopting a SUR estimation procedure to estimate the error dependence across countries, in fact, re-imposes the homogeneity of the persistence term as well as runs into practical issues of how one deals with unbalanced panels.
} 


\section{References}

Im, Kyung So, Pesaran, M. Hashem and Shin, Yongcheol. "Testing for Unit Roots in Heterogenous Panels," Journal of Econometrics, 2002, forthcoming.

Nickell,Stephen. "Biases in Dynamic Models with Fixed Effects," Econometrica 49, (November 1981): pp.1417-1426.

Table A.1: Im, Pesaran and Shin (2002) Panel Unit Root Test, $\bar{t}$

\begin{tabular}{|c|c|c|c|c|c|}
\hline $\begin{array}{c}\text { Fixed } \\
\text { Effect }\end{array}$ & $\begin{array}{c}\text { Scaled by } \\
c_{i 0}\end{array}$ & $\begin{array}{c}\text { Remove Time } \\
\text { Averages }\end{array}$ & $\bar{t}$ & $\begin{array}{c}\text { Is } \bar{t} \text { 's p-value } \\
\leq .10\end{array}$ & $\begin{array}{c}\text { Fraction of } \\
t_{i}(\rho=1)<-3.18\end{array}$ \\
\hline Yes & No & No & -1.78 & No & .08 \\
No & Yes & No & -0.93 & No & .02 \\
Yes & No & Yes & -1.87 & No & .07 \\
No & Yes & Yes & -1.23 & No & .04 \\
\hline
\end{tabular}

Notes: Regressions include all 147 countries for which data are available. I include two lags of consumption growth on the right hand side and a time trend in all cases, and a constant except where noted that I scaled the data by its initial value $c_{i 0}$. Fraction of $t_{i}(\rho=1)<-3.18$ is the fraction of individual countries $\hat{t}_{i}(\rho=1)^{\prime} s$ that are less than the univariate .10 critical value of -3.18 . 


\section{CESifo Working Paper Series}

(for full list see www.cesifo.de)

789 B. Gabriela Mundaca, Moral Hazard Effects of Bailing out under Asymmetric Information, October 2002

790 Gene M. Grossman and Edwin L.-C. Lai, International Protection of Intellectual Property, October 2002

791 John Hassler, José V. Rodriguez Mora, Kjetil Storesletten, and Fabrizio Zilibotti, A Positive Theory of Geographic Mobility and Social Insurance, October 2002

792 Paul De Grauwe and Marianna Grimaldi, The Exchange Rate in a Model with Heterogeneous Agents and Transactions Costs, October 2002

793 Guido Friebel and Mariassunta Giannetti, Fighting for Talent: Risk-shifting, Corporate Volatility, and Organizational Change, October 2002

794 Jan Erik Askildsen, Badi H. Baltagi, and Tor Helge Holmås, Will Increased Wages Reduce Shortage of Nurses? A Panel Data Analysis of Nurses' Labour Supply, October 2002

795 Marko Köthenbürger and Panu Poutvaara, Social Security Reform and Intergenerational Trade: Is there Scope for a Pareto-Improvement?, October 2002

796 Paul De Grauwe and Laura Rinaldi, A Model of the Card Payment System and the Interchange Fee, October 2002

797 Volker Böhm and Tomoo Kikuchi, Dynamics of Endogenous Business Cycles and Exchange Rate Volatility, October 2002

798 Mariam Camarero, Javier Ordóñez, and Cecilio Tamarit, The Euro-Dollar Exchange Rate: Is it Fundamental?, October 2002

799 Misa Tanaka, How Do Bank Capital and Capital Adequacy Regulation Affect the Monetary Transmission Mechanism?, October 2002

800 Jörg Baten and Andrea Wagner, Autarchy, Market Disintegration, and Health: The Mortality and Nutritional Crisis in Nazi Germany, 1933-1937, October 2002

801 Saku Aura, Uncommitted Couples: Some Efficiency and Policy Implications of Marital Bargaining, October 2002

802 Wolfram F. Richter, Delaying Integration of Immigrant Labor for the Purpose of Taxation, October 2002

803 Gil S. Epstein and Shmuel Nitzan, The Politics of Randomness, October 2002 
804 John Hassler and José V. Rodriguez Mora, Should UI Benefits Really Fall over Time?, October 2002

805 Friedrich Breyer and Stefan Felder, The Dead-anyway Effect Revis(it)ed, October 2002

806 Assar Lindbeck and Solveig Wikström, E-exchange and the Boundary between Households and Organizations, November 2002

807 Dieter Bös, Contests Among Bureaucrats, November 2002

808 Steven Brakman, Harry Garretsen, and Marc Schramm, The Strategic Bombing of German Cities during World War II and its Impact on City Growth, November 2002

809 Florian Englmaier and Achim Wambach, Contracts and Inequity Aversion, November 2002

810 Sarbajit Sengupta, Delegating Recruitment under Asymmetric Information, December 2002

811 Rajshri Jayaraman, On the Partial Public Provision of a Private Good, December 2002

812 Stéphanie Stolz, Banking Supervision in Integrated Financial Markets: Implications for the EU, December 2002

813 Christian Keuschnigg, Taxation of a Venture Capitalist with a Portfolio of Firms, December 2002

814 Inés Macho-Stadler and David Pérez-Castrillo, Settlement in Tax Evasion Prosecution, December 2002

815 Rainer Niemann and Dirk Simons, Costs, Benefits, and Tax-induced Distortions of Stock Option Plans, December 2002

816 Jan-Egbert Sturm and Barry Williams, Deregulation, Entry of Foreign Banks and Bank Efficiency in Australia, December 2002

817 V. Anton Muscatelli, Patrizio Tirelli, and Carmine Trecroci, Monetary and Fiscal Policy Interactions over the Cycle: Some Empirical Evidence, December 2002

818 Claude Hillinger, A General Theory of Price and Quantity Aggregation and Welfare Measurement, December 2002

819 Erkki Koskela and Ronnie Schöb, Optimal Capital Taxation in Economies with Unionised and Competitive Labour Markets, December 2002

820 Sheilagh Ogilvie, Guilds, Efficiency, and Social Capital: Evidence from German ProtoIndustry, December 2002

821 Hans Gersbach and Verena Liessem, Financing Democracy, December 2002 
822 Costas Hadjiyiannis, Panos Hatzipanayotou, and Michael S. Michael, Optimal Tax Policies with Private-Public Clean-Up, Cross-Border Pollution and Capital Mobility, December 2002

823 François Ortalo-Magné and Sven Rady, Homeownership: Low Household Mobility, Volatile Housing Prices, High Income Dispersion, December 2002

824 Syed M. Ahsan and Panagiotis Tsigaris, Measuring the Social Discount Rate under Uncertainty: A Methodology and Application, December 2002

825 Kai A. Konrad, Altruism and Envy in Contests: An Evolutionarily Stable Symbiosis, December 2002

826 Robert S. Chirinko and Huntley Schaller, A Revealed Preference Approach to Understanding Corporate Governance Problems: Evidence from Canada, December 2002

827 Geir B. Asheim, Green National Accounting for Welfare and Sustainability: A Taxonomy of Assumptions and Results, December 2002

828 Andrea Gebauer, Chang Woon Nam, and Rüdiger Parsche, Lessons of the 1999 Abolition of Intra-EU Duty Free Sales for Eastern European EU Candidates, December 2002

829 Giacomo Corneo, Work and Television, December 2002

830 Vivek H. Dehejia and Yiagadeesen Samy, Trade and Labour Standards - Theory, New Empirical Evidence, and Policy Implications, December 2002

831 Geir B. Asheim and Wolfgang Buchholz, A General Approach to Welfare Measurement through National Income Accounting, December 2002

832 Aaron Tornell and Frank Westermann, The Credit Channel in Middle Income Countries, January 2003

833 Gebhard Flaig, Time Series Properties of the German Monthly Production Index, January 2003

834 Campbell Leith and Jim Malley, Estimated Open Economy New Keynesian Phillips Curves for the G7, January 2003

835 Burkhard Heer and Bernd Süssmuth, Inflation and Wealth Distribution, January 2003

836 Erkki Koskela and Leopold von Thadden, Optimal Factor Taxation under Wage Bargaining - A Dynamic Perspective, January 2003

837 Carola Grün and Stephan Klasen, Growth, Income Distribution, and Well-Being: Comparisons across Space and Time, January 2003

838 Robert S. Chirinko and Ulf von Kalckreuth, On the German Monetary Transmission Mechanism: Interest Rate and Credit Channels for Investment Spending, January 2003 
839 Sascha O. Becker, Andrea Ichino, and Giovanni Peri, How Large is the "Brain Drain" from Italy?", January 2003

840 Albert Berry and John Serieux, All About the Giants: Probing the Influences on Growth and Income Inequality at the End of the $20^{\text {th }}$ Century, January 2003

841 Robert Fenge and Martin Werding, Ageing and the Tax Implied in Public Pension Schemes: Simulations for Selected OECD Countries, January 2003

842 Robert Fenge and Martin Werding, Ageing and Fiscal Imbalances Across Generations: Concepts of Measurement, January 2003

843 Giovanni Andrea Cornia, The Impact of Liberalisation and Globalisation on Income Inequality in Developing and Transitional Economies, January 2003

844 Peter Fredriksson and Per Johansson, Program Evaluation and Random Program Starts, January 2003

845 Bernd Hayo and Matthias Wrede, Fiscal Equalisation: Principles and an Application to the European Union, January 2003

846 Syed M. Ahsan and Jaideep Oberoi, Inequality, Well-being and Institutions in Latin America and the Caribbean, January 2003

847 Chang Woon Nam and Doina Maria Radulescu, The Role of Tax Depreciation for Investment Decisions: A Comparison of European Transition Countries, January 2003

848 V. Bhaskar and Steinar Holden, Wage Differentiation via Subsidised General Training, January 2003

849 Paloma Lopez-Garcia, Labour Market Performance and Start-up Costs: OECD Evidence, January 2003

850 Christian Keuschnigg and Soren Bo Nielsen, Public Policy for Start-up Entrepreneurship with Venture Capital and Bank Finance, January 2003

851 Yin-Wong Cheung, Menzie D. Chinn, and Eiji Fujii, China, Hong Kong, and Taiwan: A Quantitative Assessment of Real and Financial Integration, January 2003

852 Gregory D. Hess, The Economic Welfare Cost of Conflict: An Empirical Assessment, February 2003 